\title{
Delay of medical care for symptomatic breast cancer: A literature review
}

\author{
Karla Unger-Saldaña, MD, MSc, (I) Claudia Infante-Castañeda, BS, MSc, DSc. ${ }^{(1)}$
}

\section{Unger-Saldaña K, Infante-Castañeda C. Delay of medical care for symptomatic breast cancer: A literature review. Salud Publica Mex 2009;5 I suppl 2:S270-S285.}

\begin{abstract}
The purpose of this paper is to organize and summarize existing information on delayed medical attention for women with breast cancer and identify research needs in this area. This review is organized in six parts: origins and permanence of the message "do not delay" medical attention for potential cancer symptoms; definition and classification of breast cancer delay; impact of delay on breast cancer prognosis; factors related to breast cancer delay and the ways these have been studied; the study of breast cancer delay in Mexico; and directions for future research in developing countries, with a special focus on Mexico. We point out the need of a more integral study of delay that takes into account socio-structural and health services factors, in order to find modifiable factors towards which political actions should be directed to improve breast cancer medical attention in underdeveloped countries.
\end{abstract}

Key words: Breast neoplasms; delay; lag-time; duration of symptoms; survival; sick role; health service accessibility; health services research; review; Mexico
Unger-Saldaña K, Infante-Castañeda C.

El retraso en la atención médica del cáncer de mama: una revisión de la literatura.

Salud Publica Mex 2009;5 I supl 2:S270-S285.

\section{Resumen}

El objetivo de esta revisión es integrar información disponible con respecto al retraso en la atención médica del cáncer de mama e identificar necesidades de investigación en este tema. La revisión consta de seis apartados: origen del mensaje "no retrasar" ante la aparición de síntomas de cáncer; definición y clasificación del retraso en la atención del cáncer de mama; impacto del retraso sobre el pronóstico de la enfermedad; factores asociados con el retraso; la investigación del retraso en la atención del cáncer de mama en México; y necesidades de investigación en este tema. Se señala la necesidad de estudiar el retraso en la atención del cáncer de mama de forma más integral, tomando en cuenta características socio-estructurales y de servicios de salud, para identificar factores modificables hacia los cuales dirigir esfuerzos para mejorar la atención de esta enfermedad en países en vías de desarrollo.

Palabras clave: neoplasias de la mama; duración de síntomas; oportunidad del diagnóstico; retraso en la atención; supervivencia; rol del enfermo; accesibilidad a los servicios de salud; investigación en servicios de salud; revisión; México

(I) Facultad de Medicina de la Universidad Nacional Autónoma de México, Mexico City. 
$\mathrm{T}^{\mathrm{s}}$ he majority of breast cancer deaths occur in developing countries. ${ }^{1}$ Mortality reductions achieved in the last decades in developed countries have not been achieved in developing countries mainly because of a lack of access to early medical attention. ${ }^{2}$ Most cancer in low- and middle-income countries (LMC) are detected at later stages than in high-income countries. ${ }^{3}$ It is commonly assumed that this late diagnosis is due to the population's lack of information and to deficient coverage of screening programs. However, there are very few research studies on the reasons behind delayed medical attention for breast cancer in women in underdeveloped countries.

The purpose of this review is to organize, summarize and critically assess existing information on delayed medical attention for women with breast cancer and identify research needs in this area for LMC.

A literature review was conducted of studies on breast cancer delay published in English or Spanish language journals between 1950 and 2008. Searches were made using PubMed and Scielo electronic databases for the following terms, in English and Spanish: breast cancer delay, delay and breast carcinoma, delay and breast neoplasms, breast cancer experience, breast cancer and help seeking behavior. References from relevant studies were also used to trace other studies. Only literature on delay for breast cancer, and not other cancers, was included since factors influencing delay differ between different types of cancer. ${ }^{4-7}$

Information from 96 studies is summarized in this review. Selected studies were analyzed in order to respond to specific objectives. Results are presented in six parts, each of which corresponds to one of these objectives: I) understand the origins of the message "do not delay when you discover breast cancer signs or symptoms"; II) review the different definitions and classifications of delay used; III) analyze what is known to date regarding the impact of delay on prognosis; IV) identify factors related to delay and the most relevant methodological features of studies analyzing them; V) critically analyze available information on delay in Mexico; and thus VI) identify research needs on this topic in LMC, with a special focus in Mexico.

\section{Origin and permanence of the message "do not delay"}

While there is now scientific evidence that timely treatment of breast cancer is decisive for survival, ${ }^{8}$ this information was in the "public domain" for almost a century before the evidence existed. Since the beginning of the 20th century, women have been urged to seek medical attention as soon as they discover any lump or change in the breast. ${ }^{9}$

Since the creation of the "radical mastectomy" surgical technique developed by William Halsted in the late 19th century, a widespread belief originated among surgeons about surgery being able to "cure" patients if done "in time". ${ }^{9}$ Halsted himself wrote: "a cure for breast cancer is not only possible, but, if operated upon early, quite probable." 10 For over 70 years, research has thrown results in both directions, supporting and rejecting an association between delay and survival. Despite the controversy, the prevailing message among doctors, researchers and lay people since the beginning of the 20th century has been do not delay medical attention when discovering cancer symptoms. Nevertheless, this controversy could have contributed to hinder recognition of the importance of research on factors that could explain delay. Before we further discuss this issue, we will review the most accepted definition and classification of delay.

\section{Breast cancer delay: definition and classification}

Total delay in cancer is defined as more than three months between symptom discovery by the patient and the beginning of medical treatment. Longer delays are associated with reduced survival. ${ }^{8}$ Studies done in different countries have estimated total breast cancer delay to range from $17 \%^{11}$ in a population sample of the Saarland region in Germany to up to $42.5 \%{ }^{12}$ in a regional hospital sample in Tehran, Iran. Total delay is usually divided into patient delay and provider delay.

\section{a) Patient delay}

The first study on cancer delay where these two types of delay are described was done by Pack and Gallo in 1938. They defined "undue patient delay" as "three months or more elapsed time between discovery of symptoms and a visit to a physician." 13 This first definition has been surprisingly preserved for 70 years in most studies of patient delay, even though the time threshold was established arbitrarily.

\section{b) Provider delay}

Provider delay refers to a prolonged period of time between the initial medical consultation and the beginning of definitive treatment. It is also known as system or doctor delay. Pack and Gallo defined one month as "adequate time for the physician to take appropriate action." 13 This too was arbitrarily established. Although 
other researchers have used it, variability of the period of time used to define provider delay has been greater than that of patient delay.

Provider delay has been further divided by some authors into diagnosis delay, time between the first clinical consultation and cancer diagnosis, and treatment delay, time between diagnosis and beginning of treatment. ${ }^{14-17}$ Less frequently it has been divided into referral or general practitioner delay, time elapsed between first consultation to a primary care service and referral to a hospital, and hospital delay, time from referral to beginning of definitive cancer treatment. ${ }^{18,19}$

\section{The impact of breast cancer delay on prognosis}

In this section we argue that delay adversely affects survival due to disease progression. Study results regarding the relation between delay and the most important known prognostic factors are discussed. Table I summarizes general characteristics and results of these studies.

\section{a) Impact of breast cancer delay on survival}

This association was taken for granted during at least a century, ${ }^{9}$ but it was proved in $1999 .{ }^{8}$ Prior to this, various studies yielded contradictory findings. Differences in conclusions between studies may be due to: 1) differing sample characteristics (including patients in all clinical stages or only patients with operable cancer), 2) differences in the delay interval studied (patient, diagnostic, treatment, provider, total delay or different combinations) and 3) differences in time periods used to define delay (e.g. 1, 2, 3, 6 months, etc.).

In general, studies that found an inverse association between delay and survival times measured delay considering the time interval between symptom discovery and first consultation: either patient delay, ${ }^{20-24}$ total delay ${ }^{25-27}$ or hybrids of patient delay with subtypes of provider delay. ${ }^{27-29}$ Studies where no association was found only included women with operable tumors. ${ }^{30,31}$ As it will be discussed more thoroughly later on, evidence suggests that delay affects survival via the progression of cancer. Hence, a possible explanation for the negative findings of these studies is that for patients within a same clinical stage duration of symptoms has no impact on survival, as other studies have shown. ${ }^{23,25,27}$

The association between provider delay and survival has been more controversial. Some authors have reported no association ${ }^{19,31}$ while others have found an inverse association between diagnosis delay and survival time. ${ }^{20}$ Furthermore, others have found a direct associa- tion which might seem paradoxical, i.e. the greater the provider delay, the longer the survival. ${ }^{24}$ This has been explained as the ability of health providers to identify more advanced cases, with a probable short time of survival, and speed up the beginning of treatment. Studies in support of this argument have found that small tumors ${ }^{24,32}$ and early clinical stage ${ }^{33}$ are associated with delay, probably because diagnosis of early disease is more challenging for physicians.

In 1999, Richards and colleagues strongly contributed to clarify the controversial relationship between total delay and survival. Their meta-analysis of observational studies published between 1907 and 1996 demonstrated that women with total delays of more than three months have shorter survival times than women who start treatment within three months of symptom discovery. ${ }^{8}$ This study is the strongest evidence available to date, but has some limitations. Studies with different operational definitions of delay had to be included as well as studies that used different survival measures, although, in an attempt to make a more valid comparison, the authors subdivided studies into three different categories according to the type of survival measure used. Another limitation was that very few of the included studies considered the potential confounding effect of "leadtime bias" regarding the association between delay and survival, as the authors well recognize. Lead-time bias can occur when survival is only measured from the time of diagnosis instead of symptom discovery. As the time interval between symptom discovery and diagnosis confirmation increases, survival time is expected to be reduced. Therefore, if survival time is estimated from diagnosis confirmation the effect of delay on survival could be attributed to this lead-time effect. In order to reduce this bias, patients with delays of more than six months were excluded from the meta-analysis and comparisons were only done between patients with delays of three to six months and patients with delays of less than three months. ${ }^{8}$ In an attempt to control for this bias in later original research, these same authors measured survival both from the confirmation of diagnosis and symptom discovery. They found a significant relation between delay and both ways of measuring survival. ${ }^{27}$

These findings might be taken with skepticism by clinicians, as breast cancer can disseminate early in the course of disease..$^{34}$ It has recently been shown that even cells from ductal carcinoma in situ can metastasize. ${ }^{35}$ This could make us wonder how important could a delay of three to six months in the clinical phase of the disease actually be. While for many patients, delays between three and six months would probably not have an impact on five-year survival, ${ }^{8}$ it has been well 
Table I

\section{StUdies OF BREAST CANCER DELAY AND ITS EFFECT ON PROGNOSTIC FACTORS}

\begin{tabular}{|c|c|c|c|c|c|c|c|c|}
\hline Ref. & Year & Country & Delay Type & Operational definitions of delay & DV & $n$ & Patient characteristics & $A$ \\
\hline (30) & 1957 & USA & TD & $\begin{array}{l}\text { Symptom discovery to beginning of treatment. } \\
\text { (Months: }<2,2-6,>6 \text { ) }\end{array}$ & $\begin{array}{l}N \\
\text { OS }\end{array}$ & 1281 & $\mathrm{BC}$ patients who had radical mastectomy & $\begin{array}{l}x \\
x\end{array}$ \\
\hline \multirow{2}{*}{ (20) } & \multirow{2}{*}{1962} & \multirow{2}{*}{ USA } & PD & $\begin{array}{l}\text { Symptom discovery to }\left.\right|^{\text {st }} \text { medical consultation. } \\
(<6 \mathrm{~d},<28 \mathrm{~d},<6 \mathrm{~m},<12 \mathrm{~m})\end{array}$ & $\begin{array}{l}\text { CS } \\
\text { OS }\end{array}$ & \multirow{2}{*}{3623} & \multirow{2}{*}{ Patients with different cancers (644 BC) } & $\begin{array}{l}\sqrt{ }(\mathrm{D}) \\
\sqrt{ }(\mathrm{I})\end{array}$ \\
\hline & & & DD & $\begin{array}{l}\text { Ist medical consultation to diagnosis confirmation. } \\
(<6 \mathrm{~d},<28 \mathrm{~d} ;<6 \mathrm{~m})\end{array}$ & $\begin{array}{l}\text { CS } \\
\text { OS }\end{array}$ & & & $\begin{array}{l}\sqrt{ }(\mathrm{D}) \\
\sqrt{ }(\mathrm{I})\end{array}$ \\
\hline \multirow[b]{2}{*}{ (3I) } & \multirow[b]{2}{*}{1975} & \multirow[b]{2}{*}{ USA } & PD & $\begin{array}{l}\text { Symptom discovery to } 1^{\text {st }} \text { medical consultation. } \\
\text { (Months: }<1,1-3,>3 \text { ) }\end{array}$ & \multirow[b]{2}{*}{ OS } & \multirow[b]{2}{*}{237} & \multirow[b]{2}{*}{$\mathrm{BC}$ patients who had radical mastectomy } & $\mathrm{x}$ \\
\hline & & & SD & $\begin{array}{l}\text { |st medical consultation to beginning of treatment. } \\
\text { (Months: }<1,>1 \text { ) }\end{array}$ & & & & $x$ \\
\hline (48) & 1977 & USA & TD & $\begin{array}{l}\text { Symptom discovery to beginning of treatment. } \\
\text { (Months: } \leq 1,1.1-3,3.1-9,>9 \text { ) }\end{array}$ & $\begin{array}{l}\mathrm{T} \\
\mathrm{N}\end{array}$ & 1539 & BC patients with operable disease (stages I \& II) & $\begin{array}{l}\sqrt{ }(\mathrm{D}) \\
\sqrt{(D)}\end{array}$ \\
\hline$(28)$ & 1980 & Canada & $P D+D D$ & $\begin{array}{l}\text { Symptom discovery to diagnosis confirmation. } \\
\text { (Months: } \leq 1,2-11, \geq 12 \text { ) }\end{array}$ & $\begin{array}{l}\text { CS } \\
\text { OS }\end{array}$ & $159 \mid$ & $\begin{array}{l}\text { BC patients diagnosed in } 1945,1950,1955,1960 \text {, } \\
1965,1970,1975\end{array}$ & $\begin{array}{l}\sqrt{ }(\mathrm{D}) \\
\sqrt{ }(\mathrm{I})\end{array}$ \\
\hline$(21)$ & 1983 & USA & PD & $\begin{array}{l}\text { Symptom discovery to } I^{\text {st }} \text { medical consultation. } \\
\text { (Months: }<3,3-1 I, \geq 12 \text { ) }\end{array}$ & OS & 1497 & $\begin{array}{l}\text { BC patients treated at I (1976-1977) \& I5 NY hos- } \\
\text { pitals (1975-1979) }\end{array}$ & $\sqrt{ }(\mathrm{l})$ \\
\hline (7l) & 1983 & USA & $P D+R D$ & $\begin{array}{l}\text { Symptom discovery to arrival at hospital. } \\
\text { (Months: } \leq 1, I \text { to }<3,3 \text { to }<6, \geq 6 \text { ) }\end{array}$ & $\mathrm{T}$ & 569 & $\begin{array}{l}\text { BC patients treated at I hospital } \\
(1967-1978)\end{array}$ & $x$ \\
\hline (29) & 1983 & USA & $P D+R D$ & $\begin{array}{l}\text { Symptom discovery to arrival at hospital. } \\
\text { (Quantitative variable: months) }\end{array}$ & OS & 185 & $\begin{array}{l}\text { BC patients treated at I hospital between } 1957 \\
\text { and } 1965 .\end{array}$ & $\sqrt{ }(\mathrm{l})$ \\
\hline$(51)$ & 1983 & USA & DD & $\begin{array}{l}\text { Normal interpretation of mammogram to cancer } \\
\text { biopsy. }\end{array}$ & $\mathrm{N}$ & 165 & Women with breast lumps \& normal mammogram & $\sqrt{ }(\mathrm{D})$ \\
\hline$(22)$ & 1984 & Israel & PD & $\begin{array}{l}\text { Patient perception of delay between symptom disco- } \\
\text { very and diagnosis (yes/no) }\end{array}$ & $\begin{array}{l}\text { CS } \\
\text { OS }\end{array}$ & 2299 & Patients with different types of cancer (4/2 BC) & $\begin{array}{l}\sqrt{ }(\mathrm{D}) \\
\sqrt{ }(\mathrm{I}) \\
\end{array}$ \\
\hline$(25)$ & 1985 & USA & TD & $\begin{array}{l}\text { Symptom discovery to beginning of treatment. } \\
\text { (Months: }<3,3-6,>6 \text { ) }\end{array}$ & $\begin{array}{l}\text { CS } \\
\text { OS }\end{array}$ & 685 & $\begin{array}{l}\text { BC patients treated at one hospital between } 1962 \\
\text { and } 1969\end{array}$ & $\begin{array}{l}\sqrt{ }(\mathrm{D}) \\
\sqrt{ }(\mathrm{I})\end{array}$ \\
\hline$(23)$ & 1985 & USA & PD & $\begin{array}{l}\text { Symptom discovery to } 1^{\text {st }} \text { medical consultation. } \\
\text { (Months: } 3-6, \geq 7 \text { ) }\end{array}$ & $\begin{array}{l}\text { OS } \\
\text { CS }\end{array}$ & 4518 & $\begin{array}{l}\text { BC patients treated at MD Anderson Center } \\
(1949-1968)\end{array}$ & $\begin{array}{l}\sqrt{ }(I) \\
\sqrt{ }(\mathrm{D})\end{array}$ \\
\hline$(40)$ & 1986 & Italy & $\begin{array}{l}\mathrm{PD}+ \\
\mathrm{DD}\end{array}$ & $\begin{array}{l}\text { Symptom discovery to diagnosis confirmation. } \\
\text { (Months: } \leq 3,4-6,>6 \text { ) }\end{array}$ & $\begin{array}{c}\mathrm{CS} \\
\mathrm{T} \\
\mathrm{N}\end{array}$ & 1110 & $\begin{array}{l}\text { BC patients seen at } 63 \text { Italian public hospitals } \\
\text { (I983-1984) }\end{array}$ & $\begin{array}{l}\sqrt{ }(\mathrm{D}) \\
\sqrt{(D)} \\
\sqrt{ }(\mathrm{D})\end{array}$ \\
\hline$(26)$ & 1990 & Italy & TD & $\begin{array}{l}\text { Symptom discovery to beginning of treatment. } \\
\text { (Days: }<30,31-90,91-180,181-365,>365 \text {.) }\end{array}$ & $\begin{array}{c}\text { OS } \\
\mathrm{T} \\
\mathrm{N}\end{array}$ & 189 & $\begin{array}{l}\text { BC patients treated at two hospitals in Rome between } \\
(1982 \text {-1988) }\end{array}$ & $\begin{array}{l}\sqrt{ }(\mathrm{l}) \\
\sqrt{(D)} \\
\sqrt{ }(\mathrm{D}) \\
\end{array}$ \\
\hline$(42)$ & 1990 & USA & $\begin{array}{l}\mathrm{PD}+ \\
\mathrm{DD}\end{array}$ & $\begin{array}{l}\text { Symptom discovery to diagnosis confirmation. } \\
\text { (Weeks: } 0-2,3-12,>12 \text { ) }\end{array}$ & $\begin{array}{l}\text { CS } \\
T\end{array}$ & 1055 & $\begin{array}{l}\text { Cancer patients, residents of New Mexico, } \geq 65 \text { years } \\
\text { old (1984-1986) }\end{array}$ & $\begin{array}{l}\sqrt{(D)} \\
\mathrm{X}\end{array}$ \\
\hline (24) & 1994 & $\begin{array}{l}\text { Den- } \\
\text { mark }\end{array}$ & SD & $\begin{array}{l}\text { (> } 60 \text { days }) \\
\text { (> medical consultation to surgery. } \\
(>60 \text { days })\end{array}$ & $\mathrm{T}$ & 7608 & $\begin{array}{l}\text { BC patients registered at the Danish BC Cooperative } \\
\text { Group between } 1977 \text { \& } 1982\end{array}$ & $\begin{array}{c}\sqrt{ }(\mathrm{l}) \\
\sqrt{(D)} \\
\sqrt{ }(\mathrm{D}) \\
\sqrt{(D)} \\
\sqrt{(\mathrm{I})} \\
X \\
\end{array}$ \\
\hline$(41)$ & 1998 & UK & PD & $\begin{array}{l}\text { Symptom discovery to } 1^{\text {st }} \text { medical consultation. } \\
\text { ( } \geq 12 \text { weeks) }\end{array}$ & $\begin{array}{l}\text { CS } \\
T\end{array}$ & 185 & $\begin{array}{l}\text { BC patients with symptoms, treated at one hospital } \\
\text { (1992 \& 1994) }\end{array}$ & $\begin{array}{l}\sqrt{ }(\mathrm{D}) \\
\sqrt{ }(\mathrm{D})\end{array}$ \\
\hline (27) & 1999 & UK & TD & $\begin{array}{l}\text { Symptom discovery to beginning of treatment. } \\
\text { (Weeks: }<12,12-26,>12 \text { ) }\end{array}$ & $\begin{array}{l}\mathrm{T} \\
\mathrm{CS} \\
\text { OS }\end{array}$ & 2964 & $\begin{array}{l}\text { BC patients treated at one hospital between } 1975 \\
\& 1990\end{array}$ & $\begin{array}{c}\sqrt{ }(\mathrm{D}) \\
\sqrt{ }(\mathrm{D}) \\
\sqrt{(I)} \\
\end{array}$ \\
\hline (15) & 1999 & USA & DD & $\begin{array}{l}\text { Its medical consultation to diagnosis confirmation. } \\
\text { (Months: }<3, \geq 3 \text { ) }\end{array}$ & $\begin{array}{l}\mathrm{CS} \\
\mathrm{T} \\
\mathrm{N}\end{array}$ & 606 & $\begin{array}{l}\text { BC patients who received medical attention at one } \\
\text { of the authors' office }\end{array}$ & $\begin{array}{l}X \\
\sqrt{(D)} \\
X\end{array}$ \\
\hline (19) & 1999 & UK & TD & $\begin{array}{l}\text { Patient referral to beginning of treatment. } \\
\text { (Days: }<30,30-59,60-89,>90 \text { ) }\end{array}$ & OS & 36222 & $\begin{array}{l}\text { BC patients identified at Yorkshire Cancer Registry } \\
(1976-1995)\end{array}$ & $x$ \\
\hline$(8)$ & 1999 & UK & TD & $\begin{array}{l}\text { Symptom discovery to beginning of treatment. } \\
\text { (Months: }<3, \geq 3 \text { ) }\end{array}$ & $\begin{array}{l}\text { CS } \\
\text { OS }\end{array}$ & 87 & $\begin{array}{l}\text { Studies published between } 1907 \& 1996 \text { (87 studies, } \\
\text { 101,954 patients) }\end{array}$ & $\begin{array}{l}\sqrt{ }(\mathrm{D}) \\
\sqrt{ }(\mathrm{I})\end{array}$ \\
\hline (45) & 2001 & $\begin{array}{l}\text { Ger- } \\
\text { many }\end{array}$ & $P D+D D$ & $\begin{array}{l}\text { Symptom discovery to diagnosis confirmation. } \\
\text { (Months: } 0-1,1-3,>3 \text { ) }\end{array}$ & CS & 380 & $\begin{array}{l}\text { Residents of Saarland region, with BC diagnosed } \\
\text { by any means }\end{array}$ & $x$ \\
\hline (II) & 2002 & $\begin{array}{l}\text { Ger- } \\
\text { many }\end{array}$ & PD & $\begin{array}{l}\text { Symptom discovery to }\left.\right|^{\text {st }} \text { medical consultation. } \\
\text { (Months: } \mid-3,>3 \text { ) }\end{array}$ & CS & 280 & $\begin{array}{l}\text { Residents of the Saarland region, diagnosed with } \\
\text { symptomatic BC }\end{array}$ & $\sqrt{ }(\mathrm{D})$ \\
\hline (49) & 2002 & Canada & DD & $\begin{array}{l}\text { Abnormal mammogram to cancer diagnosis confir- } \\
\text { mation. (Weeks: } \leq 4,4-12,>12 \text { to } 20,>20 \text { to } 52,>52 \\
\text { to } 104,>104 \text { ) }\end{array}$ & $\mathrm{N}$ & 4465 & $\begin{array}{l}\mathrm{BC} \text { patients diagnosed within three years of abnormal } \\
\text { mammogram in five Canada provinces }\end{array}$ & $\begin{array}{l}\sqrt{ }(\mathrm{D}) \\
\sqrt{ }(\mathrm{D}) \\
\end{array}$ \\
\hline$(43)$ & 2003 & Iran & PD & $\begin{array}{l}\text { Symptom discovery to } 1^{\text {st }} \text { medical consultation. } \\
\text { (Months: } \leq 3,>3 \text { ) }\end{array}$ & $\begin{array}{l}\mathrm{CS} \\
\mathrm{T}\end{array}$ & 190 & $\begin{array}{l}\text { BC patients that received medical attention at } 2 \\
\text { hospitals in Tehran }\end{array}$ & $\begin{array}{l}\sqrt{ }(\mathrm{D}) \\
\sqrt{ }(\mathrm{D})\end{array}$ \\
\hline (44) & 2006 & USA & $\mathrm{DD}$ & $\begin{array}{l}\text { Ist medical consultation to diagnosis confirmation. } \\
\text { (Quantitative variable: months) }\end{array}$ & $\begin{array}{l}\mathrm{CS} \\
\mathrm{T} \\
\mathrm{N}\end{array}$ & 40 & $\begin{array}{l}\text { BC patients seen at I hospital }(1995-2005) \text {, with } \\
\text { diagnosis delay of more than three months }\end{array}$ & $\begin{array}{l}x \\
x \\
x\end{array}$ \\
\hline (39) & 2006 & UK & PD & $\begin{array}{l}\text { Symptom discovery to } 1^{\text {st }} \text { medical consultation. } \\
\text { (Weeks: }<12, \geq 12 \text { ) }\end{array}$ & CS & 69 & $\begin{array}{l}\text { BC patients } \geq 65 \text { years, diagnosed at two London } \\
\text { hospitals ( } 2002-2003)\end{array}$ & $\sqrt{ }(\mathrm{D})$ \\
\hline
\end{tabular}

Unger-Saldaña K \& Infante-Castañeda C, 2008

Abbreviations. $T D=$ total delay, $\mathrm{PD}=$ patient delay, $\mathrm{SD}=$ system delay or provider delay, $\mathrm{DD}=$ diagnosis delay, $\mathrm{RD}=$ referral delay, $\mathrm{TD}=$ treatment delay, $\mathrm{d}=$ days, $\mathrm{w}=$ weeks, $\mathrm{m}=$ months, $\mathrm{DV}=\mathrm{Dependent}$ variables, $\mathrm{OS}=$ overall survival, $C S=$ clinical stage, $\mathrm{T}=$ tumor size, $\mathrm{N}=$ lymph node involvement, $\mathrm{BC}=\mathrm{Breast} \mathrm{Cancer}, \mathrm{A}=\mathrm{Association}: \mathrm{I}=$ inverse association, $\mathrm{D}=$ direct association 
documented that as delay time increases, so does the probability of clinical progression, ${ }^{25}$ which has shown to negatively affect survival. ${ }^{25,36}$ Even though breast cancer's natural history is unpredictably heterogeneous, ${ }^{34,37}$ most studies have shown a reduction in mortality with earlier diagnosis. ${ }^{38}$ Therefore, as long as this disease can not be prevented, efforts should be kept in direction of early and adequate diagnosis and treatment.

\section{b) Impact of breast cancer delay on clinical stage}

Most studies have found that the longer the delay, the more likely a woman is diagnosed in advanced stages (Table I). Studies that have considered total delay or patient delay as independent variables (using the most accepted operational definitions) have consistently confirmed this association. . $^{1120,22,23,25-28,39-43}$ The metaanalysis performed by the London group ${ }^{8}$ also found 13 published studies that confirm this same result.

Few studies have not confirmed the relation between delay and clinical stage. ${ }^{15,44,45}$ In one such study, the time threshold used to define diagnosis delay was too broad (more than three months between first consultation to the physician and diagnosis confirmation). ${ }^{15} \mathrm{It}$ is noteworthy that the authors revised records of their own patients which is a great threat to validity. Another study where no association was found between doctor delay and clinical stage ${ }^{44}$ included a very small sample of women with delay, which impeded comparisons with women without delay. An additional study with negative findings between patient delay and clinical stage included patients diagnosed with breast cancer detected by any means (mammography screening, clinical breast examination or patient symptom discovery). ${ }^{45}$ In a latter publication these same authors reported a positive association between patient delay and clinical stage when analyzing only symptomatic women. ${ }^{11}$ In light of this evidence, and given that clinical stage has proven to affect survival, $23,25,29,36,46$ the most likely explanation for the association between delay and survival is that delay influences disease progression which in turn affects survival. Other study findings that support this hypothesis have reported the association between delay and survival to disappear when controlling for clinical stage. $23,25,27$

\section{c) Impact of breast cancer delay on tumor size}

Tumor size is one of the most important prognostic factors in breast cancer. ${ }^{7}$ After clinical stage, it is the prognostic factor that has most consistently been associated with delay. $15,24,26-28,40-43,48,49$ The longer the delay, the greater the tumor size at diagnosis. This is another indicator of delay's effect on disease progression.

\section{d) Impact of breast cancer delay on lymph} node involvement

Involvement of regional lymph nodes is another important prognostic factor in breast cancer. ${ }^{47}$ Some authors have found a significant association between total delay and regional lymph node involvement. ${ }^{26,48}$ Among studies where patient delay was measured, two found a significant association ${ }^{24,40}$ while another did not. ${ }^{50}$ In the latter only patients in clinical stage I and II were included, who by definition are patients with little or no lymph node involvement. No relationship has been found between provider delay and lymph node involvement. ${ }^{15,44}$ However, an association was found in a study that documented time elapsed between an abnormal mammogram and diagnosis confirmation of breast cancer, ${ }^{49}$ and another where time between a normal mammogram interpretation for a clinically detectable breast lump and a diagnostic biopsy was considered. ${ }^{51}$

\section{e) Impact of breast cancer delay on quality of life}

Breast cancer delay is not only associated with a reduced survival time. Given that the longer the delay, the more likely for the patient to present with large tumors and regional lymph node involvement, delay conveys a greater risk of needing more aggressive treatments. Hence, the longer the delay, the more likely it is for a woman to require mastectomy instead of conservative surgery as well as more toxic or extended adjuvant treatment. ${ }^{52}$ Patients diagnosed with advanced disease have also shown to have important psychological morbidity. ${ }^{53}$ Both these aspects strongly impact the patient's quality of life.

\section{Factors related to breast cancer delay}

Different factors have been pointed out in relation to patient and provider delay. In this section we discuss the most important factors studied in relation to patient delay and provider delay and the methodological features of these studies.

\section{a) Factors related to patient delay}

As shown in Table II, according to the systematic review done by Ramirez et al, ${ }^{54}$ the only socio-demographic factors that seemed to be strongly associated with patient de- 
Table II

\section{Factors Related to patient delay in SEeking medicAl ATtention for bReAst CANCER}

\begin{tabular}{|c|c|c|c|}
\hline \multirow[b]{2}{*}{ Factors } & \multirow[b]{2}{*}{ Qualitative studies } & \multicolumn{2}{|r|}{ Quantitative studies } \\
\hline & & Association & No association \\
\hline \multicolumn{4}{|l|}{ Socio-demographic factors } \\
\hline Marital status: single & & (5) (II) (12) (28) (43) (54)(5) (56) & (4) (7) (I 10) (32) (4I) (50) (57) (60) (III) (II2) (1 I3) \\
\hline Advanced age & & $(11)(24)(32)(54)^{(5)}(68)(114)$ & (5) (7) (28) (4I) (55) (57) (58) (60) (III) (I I0) (I I5) \\
\hline Residence in rural areas & & (12) (I16) & (32) \\
\hline $\begin{array}{l}\text { African or Hispanic ethnicity (in countries where the major- } \\
\text { ity of the population is non-Hispanic white) }\end{array}$ & & $\begin{array}{l}(5)(23)(62)(63) \\
(110)(54,113)^{(1)} \\
\end{array}$ & (4) (29) (60) (57) \\
\hline Low education & & $(12)(43)(54)^{(\ddagger)}(110)(115)$ & (4) (7) (50) (55) (58) \\
\hline Low socioeconomic level & (98) & (7) (12) (60) (62) (68) (1/3) (116) & (4) (5) (28) (54) (55) (57) (III) (110) (115) \\
\hline Accessibility barriers & $(67)(77)$ & (III) & (4) (55) \\
\hline Lack of health insurance & & (58) (III) & (4) $(110)$ \\
\hline $\begin{array}{l}\text { Activities that compete with health problem (e.g.: labor, } \\
\text { vacations, caring for an ill family member or for young } \\
\text { children, household activities, etc.) }\end{array}$ & $\begin{array}{l}(6)(59)(66)(67)(75) \\
(77)(82)(98)\end{array}$ & $(I / 2)(I / 3)$ & $(115)$ \\
\hline Adversity / life crisis in last year & & & (50) (II2) (II7) \\
\hline \multicolumn{4}{|l|}{ Knowledge and beliefs } \\
\hline Lack of cancer knowledge & $(66)(67)(69)(79)$ & $(12)(61)(68)(65)$ & (4) (54) (55) (70) (71) (1 I2) (1 16) \\
\hline $\begin{array}{l}\text { Previous experiences with family members or friends } \\
\text { that had cancer }\end{array}$ & $\begin{array}{l}\text { (6) (59) (66) (67) (74) } \\
(75)(76)\end{array}$ & (12) (43) (68) & (4I) (54) (57) (II5) \\
\hline \multicolumn{4}{|l|}{ Psychological factors } \\
\hline Fatalism & $(66)(67)(81)(80)(82)$ & $(61)(111)(112)$ & \\
\hline Denial & $(66)(67)(81)(80)$ & (68) (I 12) & (54) (119) \\
\hline Rationalization / suppression & $(66)(67)(79)(80)$ & (68) (116) & \\
\hline Anxiety / cancer worry & & (115) & (54) $(110)(116)$ \\
\hline Fear of cancer confirmation & $\begin{array}{l}(59)(66)(67)(69)(74) \\
(77)(78)\end{array}$ & (57) (III) (II2) & $(4 I)$ \\
\hline Fear of mastectomy & $(66)(67)(76)(78)$ & (68) (8I) (III) (II2) (II3) & $(115)$ \\
\hline $\begin{array}{l}\text { Fear of adverse effects on relationship with partner (inter- } \\
\text { ference with sexuality, partner's abandonment) }\end{array}$ & $(67)(78)(82)$ & & \\
\hline Fear to treatment's adverse effects & (59) (75) (76) & (39) (III) & (II5) \\
\hline Fear or lack of trust in doctors and hospitals in general & (66) (67) (82) & (68) (112) & \\
\hline Embarrassment of being examined by a doctor & (59) (66) (67) (78) (82) & (68) (III) (1 I2) & \\
\hline Low risk perception of cancer & (79) (82) (83) & (61) & (39) \\
\hline \multicolumn{4}{|l|}{ Characteristics of symptoms / signs } \\
\hline Breast symptoms other than a lump & (59) (75) & (18) (2I) (39) (4I) (57) (II3) & (32) (115) (116) \\
\hline Absence of pain & (59) & (68) & (II5) \\
\hline Initial interpretation of symptoms as "not serious" & $\begin{array}{l}\text { (59) (66) (69) (74) (75) } \\
(78)(79)(83)\end{array}$ & $\begin{array}{l}\left(\text { II) }(54)^{(\ddagger)}(57)(68)(I I I)(I I 2)\right. \\
(I / 3)(115)\end{array}$ & \\
\hline \multicolumn{4}{|l|}{ Social network and social support } \\
\hline Not talking to anyone about symptoms & (6) (78) & (39) $(41)(54)^{(\ddagger)}(116)$ & (58) (II5) \\
\hline Lack of social support & & & (4) (54) (58) \\
\hline \multicolumn{4}{|l|}{ Health service utilization habits } \\
\hline No breast cancer screening habits & $(67)(81)$ & (32) (46) (50) (I/3) (120) & (4I) (54) (55) \\
\hline $\begin{array}{l}\text { Past experiences of health service utilization for other } \\
\text { health problems }\end{array}$ & & $\begin{array}{l}(4)(I I)(12)(39)(I I I)(I 13)(I 15) \\
(I 16)\end{array}$ & (54) \\
\hline Lack of a regular physician & (98) & (II) (I2) (III) (II0) & \\
\hline Use of alternative medicine & (78) (8I) (82) & (68) (II3) & \\
\hline
\end{tabular}

Unger-Saldaña K \& Infante-Castañeda C, 2008

* References highlighted in bold indicate meta-analysis studies when placed in the Quantitative studies columns and meta-synthesis when placed under Qualitative studies. References in italics are reviews without meta-analysis. Remaining references correspond to original research studies

₹ Moderate evidence according to Ramírez et al's meta analysis (data are suggestive of an effect, with at least two studies in support of the direction of the effect, but conclusions could be affected by a new study with a large sample)

\& Strong evidence (a substantially greater proportion of studies point to one direction than one would expect to happen by chance) 
lay up to 1999 were the patient's single marital status and advanced age. However, subsequent studies have continued to come up with contradictory results. ${ }^{5,7,11,12,32,43,50,55-58}$ There seems to be consensus regarding the influence on delay of presenting breast symptoms different from a lump $18,21,39,41,57,59$ and the patient's initial interpretation of her symptoms as "not serious."11,54,57,59 Though not conclusive, other factors that seem to be of great importance are low education and ethnicity other than non-Hispanic white (in countries where the majority of the population is Caucasian). ${ }^{54}$ Several studies report a reduced survival time of Hispanic-American and African-American patients ${ }^{23,46,60}$ as well as breast cancer diagnosis at more advanced clinical stages ${ }^{23,46,61-63}$ in comparison to nonHispanic white American patients.

The association between socioeconomic status (SES) and delay has not been firmly demonstrated. Nevertheless, it can not be ruled out since the different ways this variable has been measured are not comparable between studies. SES is most likely related to delay as it is a "powerful determinant of possessing particular health enhancing resources." ${ }^{64}$ Many of the factors that have shown to be related to delay are likely to be associated with a low SES, e.g. belonging to an ethnic minority, low education, rural residence, lack of health insurance, access barriers to care and activities that compete with medical attention.

It is noteworthy that despite the fact that some studies have documented an inverse relation between cancerrelated knowledge and delay, $12,61,65-69$ this has not been proven in the majority of quantitative studies ${ }^{54}$ Health professionals have been compared with lay people and no differences in delay have been found..$^{70,71}$ This lack of relation between knowledge and practice has also been documented for other illness behaviors. ${ }^{72,73}$

The patient's knowledge of other people with cancer has emerged in several qualitative studies as a relevant factor influencing help seeking behavior., ${ }^{6,59,74-76} \mathrm{Nev}-$ ertheless, results about this association have been controversial in quantitative studies. ${ }^{12,41,43,54,57}$ Once more, the way this variable is operationalized and measured is inconsistent between studies, making it difficult to reach conclusions.

Among the psychological factors that have been studied in relation to delay, fear deserves a special comment. Fear has been shown to have a curvilinear association with patient delay; it can either accelerate seeking of medical attention ${ }^{76-79}$ or it can cause delay. ${ }^{59,74-76,78,79}$ The mechanisms that determine one patient with fear to act one way or the other have still not been elucidated. In addition, different kinds of fears have been measured using different instruments, which further complicates comparisons between studies.
We identified a lack of high quality quantitative studies that measure the role of certain relevant factors found in qualitative studies, such as: fatalism, $66,67,80-82$ denial, ${ }^{66,67,80,81,83}$ rationalization/ suppression, $66,67,79,80 \mathrm{em}$ barrassment of being examined by a doctor, $59,66,67,78$ and risk perception. ${ }^{79,82,83}$ It is interesting to highlight that studies on breast cancer risk perception have shown that the majority of women underestimate their personal risk to develop breast cancer, ${ }^{83-85}$ which might exert an important influence on early detection practices and on delayed medical attention for breast symptoms. Finally, we detected very few studies on the role of social networks and social support in breast cancer delay.

\section{b) Factors related to provider delay}

Table III summarizes factors in relation to provider delay. As can be observed when comparing between Tables II and III, this type of delay has been a lot less studied than patient delay. We believe this is a reflection of two trends: 1) the minimization of socio-medical and health services research that competes with the overwhelming advances in biomedical knowledge and technology and 2) the fact that the medical model has traditionally attributed health problems and lack of their medical attention to the affected individuals, thus blaming the "victim," 86 which causes social problems to be reduced to individual behaviors without consideration of the influence exerted by the socio-structural factors and inequity that lead to a differential distribution of disease, access to health services and quality of care.

Among the most studied factors in relation to provider delay we again find characteristics of the patient: young age $5,7,32,54,87$ and having breast symptoms other than a tumor ${ }^{54,87,88}$ both of which make the physician's diagnosis more difficult; having African or Hispanic ethnicity in countries where the majority of the population is Caucasian $^{14,17,54,57,89}$ and low socioeconomic status. ${ }^{5,57,87,90}$ While there seems to be consensus regarding young age and presenting symptoms different from a breast lump, the relation of provider delay with ethnicity and SES is still controversial. They have both been deficiently measured in order to understand how they intervene with timely medical attention through availability, accessibility and acceptability of health services. Nevertheless, the way these variables have been conceptualized allocate delay responsibility on the patient as an individual instead of dealing with the much more complex problem of understanding the ways in which health systems are inequitable with minorities and with the poor.

Even though health services are considered as important actors in the study of delay, the few investigations that address provider delay reduce the problem to 
Table III

FACTORS RELATED TO PROVIDER DELAY IN MEDICAL ATTENTION FOR BREAST CANCER

\begin{tabular}{|c|c|c|c|}
\hline \multirow[b]{2}{*}{ Factors } & \multirow[t]{2}{*}{$\begin{array}{l}\text { Qualitative } \\
\text { studies }\end{array}$} & \multicolumn{2}{|l|}{ Quantitative studies } \\
\hline & & Association & No association \\
\hline \multicolumn{4}{|l|}{ Patient and symptom characteristics } \\
\hline Patient's young age & & $(5)(16)(19)(24)(32)(51)(54)^{(5)}(87)(88)(121)(89)(113)$ & $(7)(15)(57)(90)$ \\
\hline $\begin{array}{l}\text { Patient's African or Hispanic ethnicity (in countries where the majority of } \\
\text { the population is non-Hispanic white) }\end{array}$ & & $(14)(17)(54)^{(\ddagger)}$ & (15) (57) (12I) (89) \\
\hline Low socioeconomic level & & (5) (90) & (57) (87) \\
\hline Breast signs or symptoms other than a lump & & $(18)(4 I)(54)^{(8)}(87)(88)(12 I)(89)(I I 3)$ & \\
\hline Early clinical stage or small tumor size & & (24) (32) (33) & \\
\hline \multicolumn{4}{|l|}{ Quality of health services } \\
\hline Medical errors in diagnosis & (6) (67) & (14) (15) (18) (5I) (56) (88) (90) (89) (92) (9I) (II2) (1/3) & (54) \\
\hline Administrative barriers to health care & (97) & (89) (II2) & \\
\hline Far distance from residence to cancer centers & & & $(87)$ \\
\hline \multicolumn{4}{|l|}{ Unger-Saldaña K \& Infante-Castañeda C, 2008} \\
\hline \multicolumn{4}{|c|}{$\begin{array}{l}\text { * References highlighted in bold indicate meta-analysis studies when placed in the Quantitative studies columns and meta-synthesis when placed under Qualitative studies. References } \\
\text { in italics are reviews without meta-analysis. Remaining references correspond to original research studies }\end{array}$} \\
\hline \multicolumn{4}{|c|}{$\begin{array}{l}\text { Moderate evidence according to Ramírez et al's meta analysis (data are suggestive of an effect, with at least } 2 \text { studies in support of the direction of the effect, but conclusions could } \\
\text { be affected by a new study with a large sample) }\end{array}$} \\
\hline Strong evidence (a substantially greater proportion of studies point to $c$ & ction $\mathrm{t}$ & e would expect & \\
\hline
\end{tabular}

estimation of delay time intervals and to finding whose fault it was; if it isn't the patient, then the doctors are the ones usually blamed. This is reflected in the most common remaining variables studied in relation to provider delay (Table III), medical errors, manifested either as the primary care physician's failure to suspect cancer at initial visit ${ }^{18,56,89}$ or as false negative interpretations of mammography ${ }^{14,15,51,88,90-92}$ or biopsy. ${ }^{88,90}$ The study of the real problems of health services accessibility and quality at a health system level -which can have an effect, for example, on breast cancer delayed medical attention- is practically non-existent. ${ }^{93}$

\section{c) Methodological features of studies on factors related to delay}

Knowledge of factors associated with breast cancer delay that have been studied helps to understand how the study of delay has been constructed. Nevertheless, research strategies and methods also constitute a determinant factor in the advance of scientific knowledge. It is therefore also necessary to explore the methodological evolution of research studies on delay to more comprehensively understand past achievements and constraints to be overcome in future research.

Table IV presents general characteristics of studies that analyzed the factors listed in Tables II and III. As it can be observed, the majority of studies use quantitative methods which aren't very helpful for a deep understanding of the underlying reasons why women delay seeking medical attention and the health services obstacles they are confronted with.

Among quantitative studies, the following issues called our attention: 1) There is an evident lack of population based studies which accounts for the lack of information on women with breast cancer that never reach health services for medical attention; 2) Since a prospective study on delay is unethical, all studies are retrospective, which implies certain limitations. The most mentioned limitation throughout studies on delay is recall bias, i.e. women might report wrong dates and delay time because they don't remember well. Nonetheless, it has been shown that usually women do recall quite well the beginning of their symptoms. ${ }^{41,94}$ Another limitation of retrospective studies is that patients may report less delay than they really experimented in an effort to please the interviewer with "an adequate answer"; 3) Some studies used self-administered questionnaires which have the disadvantage of lower participation rates, specially if it is a postal questionnaire, ${ }^{95}$ and the threat of selection bias. People who participate in this type of survey are usually more interested in their own health, fact that is probably linked with timely medical care seeking, in comparison to people that do not bother to answer the questionnaire; 
Table IV

\section{Characteristics of Studies that analyze factors IN RELATION TO BREAST CANCER Delay}

\begin{tabular}{|c|c|c|c|c|c|c|c|}
\hline Ref. & Year & Country & Dependent variables & $\begin{array}{c}\text { Source of } \\
\text { information }\end{array}$ & $n$ & Patients & Data analysis \\
\hline$(\mathrm{III})$ & 1950 & USA & $\begin{array}{l}\mathrm{PD}=\text { symptom discovery to } \mathrm{I}^{\text {st }} \text { consul- } \\
\text { tation. }(>3 \mathrm{~m})\end{array}$ & Semistructured interviews & 329 & $\begin{array}{l}\text { Random sample of people with cancer } \\
\text { symptoms seen at one hospital }\end{array}$ & Bivariate analysis. \\
\hline$(80)$ & 1951 & USA & $\begin{array}{l}\text { PD= Patient postpones medical } \\
\text { consultation. (NS) }\end{array}$ & In depth interviews & NS & $\begin{array}{l}\text { Cancer patients referred for psychiatry } \\
\text { consultation in one hospital. }\end{array}$ & $\begin{array}{l}\text { Defensive ma- } \\
\text { neuvers theory }\end{array}$ \\
\hline$(70)$ & 1953 & USA & $\begin{array}{l}\mathrm{PD}=\text { symptom discovery to } \mathrm{I}^{\text {st }} \text { consul- } \\
\text { tation. }(>3 \mathrm{~m})\end{array}$ & Medical records & 229 & $\begin{array}{l}\text { Doctors with cancer seen at one hospital. } \\
\text { (Compared with } 2000 \text { lay patients) *9 } \\
\text { doctors with BC }\end{array}$ & Bivariate analysis \\
\hline$(68)$ & 1954 & USA & $\mathrm{PD}=$ Delay caused by the patient. (NS) & $\begin{array}{l}\text { Semistructured interviews + } \\
\text { personality tests }\end{array}$ & 100 & $\begin{array}{l}\text { Random sample of cancer patients atten- } \\
\text { ded at one hospital ( } 50 \text { with Delay and } 50 \\
\text { without Delay) }\end{array}$ & Bivariate analysis \\
\hline$(66)$ & 1955 & UK & $\begin{array}{l}\mathrm{PD}=\text { symptom discovery to } \mathrm{I}^{\text {st }} \text { consul- } \\
\text { tation. }(\geq 3 \mathrm{~m})\end{array}$ & Interviews + IQ instrument & 314 & $\begin{array}{l}\text { Cancer patients (breast, cervix, oral cavity } \\
\text { or skin) attended at one hospital }\end{array}$ & Descriptive \\
\hline$(116)$ & 1957 & USA & $\begin{array}{l}\mathrm{PD}=\text { symptom discovery to } \mathrm{I}^{\mathrm{st}} \text { consul- } \\
\text { tation. }(\geq 3 \mathrm{~m})\end{array}$ & Interviews & 727 & $\begin{array}{l}\text { People with potential cancer symptoms } \\
\text { seen at NY clinics }\end{array}$ & $\begin{array}{l}\text { Bivariate \& strati- } \\
\text { fied analysis. }\end{array}$ \\
\hline$(60)$ & 1959 & USA & $\begin{array}{l}\mathrm{PD}=\text { symptom discovery to }\left.\right|^{\text {st }} \text { consul- } \\
\text { tation. }(>\mid \mathrm{m})\end{array}$ & Medical records & 633 & BC 9 treated at I hospital $(1943-1951)$ & Bivariate analysis \\
\hline$(67)$ & 1964 & USA & $\begin{array}{l}\mathrm{PD}=\text { symptom discovery to } \mathrm{I}^{\mathrm{st}} \text { consul- } \\
\text { tation. }(>2 \mathrm{~m})\end{array}$ & Interviews & 150 & $\begin{array}{l}\text { i with breast symptoms referred to one } \\
\text { hospital }\end{array}$ & $\begin{array}{l}\text { Psycho-analytic } \\
\text { theory }\end{array}$ \\
\hline$(115)$ & 1968 & UK & $\begin{array}{l}\mathrm{PD}=\text { symptom discovery to } \mathrm{I}^{\text {st }} \text { consul- } \\
\text { tation. }(>1 \mathrm{~m})\end{array}$ & $\begin{array}{l}\text { Structured interviews + self- } \\
\text { administered questionnaires }\end{array}$ & 83 & $\begin{array}{l}\text { O hospitalized for operation of breast } \\
\text { tumors (benign or malignant) }\end{array}$ & Bivariate analysis \\
\hline$(I \mid 2)$ & 1974 & UK & $\begin{array}{l}\mathrm{PD}=\text { symptom discovery to }\left.\right|^{\text {st }} \text { consul- } \\
\text { tation. }(>3 \mathrm{~m})\end{array}$ & $\begin{array}{l}\text { Psychiatric interviews + } \\
\text { psychological tests }\end{array}$ & 160 & $\begin{array}{l}\text { } \text { hospitalized for breast lump biopsy; ( } 69 \\
\text { cancers; } 91 \text { benign) }\end{array}$ & Bivariate analysis \\
\hline$(28)$ & 1980 & Canada & $\begin{array}{l}\text { Delay= symptom discovery to } \mathrm{BC} \text { final } \\
\text { diagnosis. }(>\mathrm{I})\end{array}$ & Medical records & |59| & $\begin{array}{l}\text { BC patients diagnosed in } 1945,1950,1955 \text {, } \\
1960,1965,1970 \& 1975\end{array}$ & Bivariate analysis \\
\hline$(120)$ & 1981 & USA & $\begin{array}{l}\mathrm{DD}=\text { symptom discovery to }\left.\right|^{\text {st }} \text { consul- } \\
\text { tation. }(>2 \text { to } \leq 6,>6 \mathrm{~m})\end{array}$ & Structured interviews & 2092 & $\begin{array}{l}\text { BC } 9 \text { diagnosed in } 14 \text { hospitals of Georgia } \\
(1975+1979)\end{array}$ & Bivariate analysis \\
\hline$(18)$ & 1981 & UK & $\begin{array}{l}\mathrm{PD}=\text { symptom discovery to }\left.\right|^{\mathrm{st}} \text { consul- } \\
\text { tation. }(\leq \mathrm{I} w, \leq 3 \mathrm{~m}, \leq 6 \mathrm{~m}) \\
\mathrm{GPD}=\mathrm{I}^{\text {st }} \text { consultation to treatment } \\
\text { referral. }(\leq 2 \mathrm{w}, \leq 3 \mathrm{~m}) \\
\mathrm{HD}=\text { referral to treatment. (NS) }\end{array}$ & $\begin{array}{l}\text { Structured interviews + } \\
\text { Medical records }\end{array}$ & 145 & $\begin{array}{l}\mathrm{BC} \text { q diagnosed in four public hospitals of } \\
\text { Northwestern England. }\end{array}$ & Bivariate analysis \\
\hline (7I) & 1983 & USA & $\begin{array}{l}\text { Delay= symptom discovery to arrival } \\
\text { at } 3^{\text {rd }} \text { level hospital. } \\
(1 \text { to }<3,3 \text { to }<6, \geq 6 \mathrm{~m})\end{array}$ & Medical records & 569 & $\begin{array}{l}\text { BC } \text { o operated at one hospital (1967 - } \\
1978) . * 27 / 569 \text { health professionals }\end{array}$ & Bivariate analysis \\
\hline$(2 \mathrm{I})$ & 1983 & USA & $\begin{array}{l}\mathrm{PD}=\text { symptom discovery to } \mathrm{I}^{\mathrm{st}} \text { medical } \\
\text { consultation. }(\geq 3 \mathrm{~m})\end{array}$ & $\begin{array}{l}\text { Structured interviews + } \\
\text { Medical records }\end{array}$ & 664 & $\begin{array}{l}\text { BC patients seen in } 15 \text { Brooklyn hospitals } \\
(1975-1979)\end{array}$ & Bivariate analysis \\
\hline (29) & 1983 & USA & $\begin{array}{l}\text { TD= symptom discovery to arrival at } \\
\text { hospital. } \\
\text { (Quantitative variable: months) }\end{array}$ & $\begin{array}{l}\text { Structured interviews + } \\
\text { Medical records }\end{array}$ & 185 & $\begin{array}{l}\text { BC }+ \text { admitted to a hospital between } 1957 \\
\& 1965 . \\
\text { (29/185 African-American) }\end{array}$ & Bivariate analysis \\
\hline$(5 \mathrm{I})$ & 1983 & USA & $\begin{array}{l}\mathrm{DD}=\text { normal mammogram to } \mathrm{BC} \\
\text { biopsy. (NS) }\end{array}$ & Medical records & 165 & $\begin{array}{l}\text { s+ with palpable breast masses \& normal } \\
\text { mammograms }\end{array}$ & Bivariate analysis \\
\hline$(119)$ & 1984 & UK & $\begin{array}{l}\text { Delay= symptom discovery to } I^{\text {st }} \\
\text { consultation. }(I \text { to }<5 \mathrm{w}, 5 \text { to }<12 \mathrm{w},> \\
\mathrm{I} 2 \mathrm{w} \text { to }<6 \mathrm{~m},>6 \mathrm{~m})\end{array}$ & $\begin{array}{l}\text { Structured interviews + } \\
\text { psychological tests }\end{array}$ & 24 & Hospitalized BC $q$ who had breast surgery. & Bivariate analysis \\
\hline$(23)$ & 1985 & USA & $\begin{array}{l}\mathrm{PD}=\text { symptom discovery to } \mathrm{I}^{\text {st }} \text { consul- } \\
\text { tation. }(3-6 \mathrm{~m}, \geq 7 \mathrm{~m})\end{array}$ & Medical records & 4518 & $\begin{array}{l}\text { BC } 9 \text { treated at MD Anderson Cancer } \\
\text { Center }(1949-1968)\end{array}$ & Bivariate analysis \\
\hline$(46)$ & 1988 & USA & $\begin{array}{l}\mathrm{PD}=\text { symptom discovery to } \mathrm{I}^{\text {st }} \text { consul- } \\
\text { tation. }(>2 \mathrm{~m})\end{array}$ & $\begin{array}{l}\text { Structured interviews + } \\
\text { Medical records }\end{array}$ & 2083 & $\begin{array}{l}\text { BC } 9 \text { diagnosed at I4 hospitals of Georgia } \\
(1975-1979)\end{array}$ & Bivariate analysis. \\
\hline (4) & 1988 & USA & $\begin{array}{l}\mathrm{PD}=\text { symptom discovery to } \mathrm{I}^{\text {st }} \text { consul- } \\
\text { tation. ( } 3 \text { to } \mathrm{I} 2,>12 \mathrm{w})\end{array}$ & Structured interviews & 800 & $\begin{array}{l}\text { New Mexico } \geq 65 \text { old residents with } \\
\text { cancer }(1984-1986) * 194 \text { BC cases }\end{array}$ & Bivariate analysis. \\
\hline$(63)$ & 1992 & USA & $\begin{array}{l}\text { Symptom duration= symptom disco- } \\
\text { very to } \mathrm{I}^{\text {st }} \text { consultation. (Quantitative } \\
\text { variable: days) }\end{array}$ & $\begin{array}{l}\text { Structured interviews + } \\
\text { Medical records }\end{array}$ & 735 & $\begin{array}{l}\text { BC }+ \text { residents of Atlanta, New Orleans \& } \\
\text { San Francisco (I985-86) (Afro-Americans } \\
\& \text { whites matched by age and geographic } \\
\text { area) }\end{array}$ & $\begin{array}{l}\text { Multivariate } \\
\text { analysis }\end{array}$ \\
\hline$(62)$ & 1992 & USA & $\begin{array}{l}\mathrm{DD}=\text { symptom discovery to final } \mathrm{BC} \\
\text { diagnosis. }\end{array}$ & $\begin{array}{l}\text { Cancer registry of Los } \\
\text { Angeles }\end{array}$ & 23567 & $\begin{array}{l}\text { BC Los Angeles residents } \\
(1977-1985)\end{array}$ & $\begin{array}{l}\text { Multivariate } \\
\text { analysis }\end{array}$ \\
\hline$(113)$ & 1993 & USA & $\begin{array}{l}\mathrm{PD}=\text { symptom discovery to } \mathrm{I}^{\text {st }} \text { consul- } \\
\text { tation. }(\geq 3 \mathrm{~m}) \\
\mathrm{SD}=\mathrm{I}^{\text {st }} \text { beginning consultation to } \\
\text { treatment. }(>\mid \mathrm{m})\end{array}$ & Literature review & 101 & $\begin{array}{l}\text { Delay studies published in English between } \\
1975 \text { and } 1993\end{array}$ & Critical review \\
\hline$(110)$ & 1993 & USA & $\begin{array}{l}\text { PD= symptom discovery to }\left.\right|^{\text {st }} \\
\text { consultation. } \\
\text { (Quantitative variable: days) }\end{array}$ & $\begin{array}{l}\text { Semistructured interviews + } \\
\text { psychological tests }\end{array}$ & 106 & $\begin{array}{l}\text { I with self-discovered breast symptoms } \\
\text { referred to two teaching hospitals }\end{array}$ & $\begin{array}{l}\text { Multivariate } \\
\text { analysis }\end{array}$ \\
\hline$(24)$ & 1994 & $\begin{array}{l}\text { Den- } \\
\text { mark }\end{array}$ & $\begin{array}{l}P D=\text { symptom discovery to } I^{\text {st }} \text { consul- } \\
\text { tation. }(>60 \mathrm{~d}) \\
D D=I^{\text {st }} \text { medical consultation to } \\
\text { surgery or biopsy. }(>60 \mathrm{~d})\end{array}$ & $\begin{array}{l}\text { National database } \\
\text {-(DBCG) Danish BC } \\
\text { Cooperative Group }\end{array}$ & 7608 & $\begin{array}{l}\text { BC patients registered in the DBCG } \\
\text { between } 1977 \text { and } 1982\end{array}$ & $\begin{array}{l}\text { Multivariate } \\
\text { analysis }\end{array}$ \\
\hline
\end{tabular}


(Continued)

\begin{tabular}{|c|c|c|c|c|c|c|c|}
\hline$(12 \mid)$ & 1995 & USA & $\begin{array}{l}\mathrm{SD}=\left.\right|^{\text {st }} \text { medical consultation to } \mathrm{BC} \\
\text { final diagnosis. } \\
\text { (Quantitative variable: days) }\end{array}$ & $\begin{array}{l}\text { Structured interviews }+ \\
\text { Medical records ( } \mathrm{NCl} \\
\text { Black/white Cancer Survival } \\
\text { Study) }\end{array}$ & 996 & $\begin{array}{l}\text { Cohort of African-American and white BC } \\
\text { patients residents of Atlanta, New Orleans } \\
\text { and San Francisco (I985-1986).*519 } \\
\text { African-Americans \& } 477 \text { white Americans }\end{array}$ & $\begin{array}{l}\text { Multivariate } \\
\text { analysis }\end{array}$ \\
\hline (77) & 1995 & USA & $\begin{array}{l}\text { Delay= symptom discovery to }\left.\right|^{\text {st }} \\
\text { contact with health services - personal } \\
\text { or by phone. }(>3 \mathrm{~m})\end{array}$ & In depth interviews & 138 & $\begin{array}{l}\text { o with self-discovered breast symptoms } \\
\text { referred to two teaching hospitals }\end{array}$ & Content analysis \\
\hline (89) & 1996 & USA & $\begin{array}{l}S D=\left.\right|^{\text {st }} \text { medical consultation to final } \\
\mathrm{BC} \text { diagnosis. }(>4 \mathrm{~m})\end{array}$ & $\begin{array}{l}\text { Structured interviews + } \\
\text { Medical records ( } \mathrm{NCl} \\
\text { Black/white Cancer Survival } \\
\text { Study) }\end{array}$ & 367 & $\begin{array}{l}\text { Cohort of African-American and white BC } \\
\text { patients residents of Atlanta, New Orleans } \\
\text { and San Francisco, who experienced } \\
\text { system delay (1985-1986) }\end{array}$ & Bivariate analysis \\
\hline$(118)$ & 1997 & USA & $\begin{array}{l}\mathrm{PD}=\text { symptom discovery to } \mathrm{I}^{\text {st }} \text { consul- } \\
\text { tation. }(>3 \mathrm{~m})\end{array}$ & Case descriptions & 5 & $\begin{array}{l}\text { Cancer patients with psychiatric problems } \\
\& \text { delay or no adherence }\end{array}$ & $\begin{array}{l}\text { Psychiatricde- } \\
\text { scription }\end{array}$ \\
\hline$(I \mid 4)$ & 1998 & UK & $\begin{array}{l}\text { Concealed cancer= patient with breast } \\
\text { lump that doesn't seek medical help. } \\
(\geq 6 \mathrm{~m})\end{array}$ & Medical records & 170 & $\begin{array}{l}\text { BC } 9 \text { between } 1988 \text { and } 1992 \text { in one } \\
\text { general hospital }\end{array}$ & Bivariate analysis \\
\hline$(4 I)$ & 1998 & UK & $\begin{array}{l}\mathrm{PD}=\text { symptom discovery and } \mathrm{I}^{\text {st }} \\
\text { consultation }(\geq 3 \mathrm{~m}) \\
\mathrm{GPD}=\text { failure to refer patient to a } 3^{\text {rd }} \\
\text { level hospital after } \mathrm{I}^{\text {st }} \text { visit. }\end{array}$ & Semistructured interviews & 185 & $\begin{array}{l}\text { Two series: I) Cohort of } \mathrm{BC}+\text { aged }<60 \\
(|4|) \text {; } 2 \text { Case control: patients aged } \geq 60 \text {, } \\
\text { inoperable cancers matched with operable } \\
\text { tumors }\end{array}$ & $\begin{array}{l}\text { Multivariate } \\
\text { analysis }\end{array}$ \\
\hline (78) & 1998 & USA & $\begin{array}{l}\text { Women's opinions about actions they } \\
\text { would take if they discovered a breast } \\
\text { symptom. }\end{array}$ & Focus groups & 80 & $\begin{array}{l}\text { Voluntary }+ \text { with no cancer recruited in } \\
\text { communitarian organizations other than } \\
\text { health care services. }\end{array}$ & $\begin{array}{l}\text { Narrative } \\
\text { analysis }\end{array}$ \\
\hline$(61)$ & 1998 & USA & $\begin{array}{l}\text { Advanced } B C \text { clinical stage }= \\
\text { patients with } B C \text { stages III \& IV. }\end{array}$ & $\begin{array}{l}\text { Structured interviews + } \\
\text { Medical records }\end{array}$ & 954 & $\begin{array}{l}\text { Cases: } 540 \text { BC } 9 \text { diagnosed at one hospital } \\
(1985-1992) \text {. Controls: } 414+\text { matched by } \\
\text { age, race \& residence. }\end{array}$ & $\begin{array}{l}\text { Multivariate } \\
\text { analysis }\end{array}$ \\
\hline$(54)$ & 1999 & UK & $\begin{array}{l}\mathrm{PD}=\text { symptom discovery and } \mathrm{I}^{\text {st }} \\
\text { consultation. }(\geq 3 \mathrm{~m}) \\
\mathrm{SD}=\mathrm{I}^{\text {st }} \text { medical consultation to } \\
\text { treatment. }(\geq 3 \mathrm{~m})\end{array}$ & $\begin{array}{l}\text { Critical and systematic } \\
\text { review of the literature }\end{array}$ & 23 & $\begin{array}{l}\text { Cohort or case-control studies, published } \\
\text { after } 1960 \text {, with samples of only patients } \\
\text { with BC, with validated measure of the } \\
\text { involved factor, \& that described a discrete } \\
\text { interval of delay ( } 23 \text { out of I0I original } \\
\text { studies) }\end{array}$ & $\begin{array}{l}\text { No meta- } \\
\text { analysis. Strength } \\
\text { of evidence } \\
\text { estimated for } \\
\text { each factor. }\end{array}$ \\
\hline (19) & 1999 & UK & $\begin{array}{l}S D=\left.\right|^{\text {st }} \text { medical consultation to treat- } \\
\text { ment. }(30-59,60-89,>90 d)\end{array}$ & Yorkshire Cancer Registry & 36222 & $\begin{array}{l}\text { BC patients diagnosed between } 1976 \text { and } \\
1995\end{array}$ & $\begin{array}{l}\text { Multivariate } \\
\text { analysis }\end{array}$ \\
\hline$(15)$ & 1999 & USA & $\begin{array}{l}\mathrm{DD}=\mathrm{I}^{\text {st }} \text { consultation to } \mathrm{BC} \text { final } \\
\text { diagnosis. }(\geq 3 \mathrm{~m})\end{array}$ & Medical records & 606 & $\begin{array}{l}\text { BC patients seen at the office of one of } \\
\text { the authors }\end{array}$ & Bivariate analysis \\
\hline$(117)$ & 2000 & UK & $\begin{array}{l}\mathrm{PD}=\text { symptom discovery to } \mathrm{I}^{\text {st }} \text { consul- } \\
\text { tation. }(\geq 12 \mathrm{w})\end{array}$ & $\begin{array}{l}\text { Semistructured interviews } \\
+ \text { adverse life events \& } \\
\text { psychiatric tests }\end{array}$ & 185 & $\begin{array}{l}2 \text { series: I) Cohort of } \mathrm{BC}+9 \text { aged }<60 \\
(|4|) ; 2) \text { Case control: patients aged } \geq 60 \text {, } \\
\text { inoperable cancers matched with operable } \\
\text { tumors }\end{array}$ & Bivariate analysis \\
\hline$(14)$ & 2000 & USA & $\begin{array}{l}\text { Diagnosis interval= abnormal mammo- } \\
\text { gram to } \mathrm{BC} \text { diagnosis. }(>60 \mathrm{~d}) \\
\text { Treatment interval= final diagnosis to } \\
\text { treatment. }(>30 \mathrm{~d})\end{array}$ & $\begin{array}{l}\text { National Breast and Cervi- } \\
\text { cal Cancer Early Detection } \\
\text { Program (NBCCEDP) }\end{array}$ & 1659 & $\begin{array}{l}\text { NBCCEDP participants with } B C \text { detected } \\
\text { through screening mammography or clinical } \\
\text { breast examination }\end{array}$ & Bivariate analysis \\
\hline$(82)$ & 2000 & USA & $\begin{array}{l}\text { Women's opinions about actions they } \\
\text { would take if they discovered a breast } \\
\text { symptom. }\end{array}$ & Focus groups & 45 & $\begin{array}{l}\text { Voluntary Chinese-American }+ \text { with no } \\
\text { cancer recruited in community organiza- } \\
\text { tions (no health services). }\end{array}$ & Content analysis \\
\hline$(88)$ & 2000 & UK & $\begin{array}{l}\mathrm{HD}=\mathrm{I}^{\text {st }} \text { consultation to } \mathrm{BC} \text { diagnosis. } \\
(\mathrm{QV}: \mathrm{m})\end{array}$ & Medical records & 1004 & $\begin{array}{l}\text { BC } q \text { in one hospital between } 1988 \text { and } \\
1997\end{array}$ & Bivariate analysis \\
\hline$(57)$ & 2000 & UK & $\begin{array}{l}\mathrm{PD}=\text { symptom discovery to } \mathrm{I}^{\text {st }} \text { consul- } \\
\text { tation. }(\mathrm{QV}: \mathrm{d}) \\
\mathrm{SD}=\mathrm{I}^{\text {st }} \text { medical consultation to }\left.\right|^{\text {st }} \\
\text { consultation with specialist. }(\mathrm{QV}: \mathrm{d})\end{array}$ & $\begin{array}{l}\text { Semistructured interviews } \\
+ \text { Medical records }\end{array}$ & 692 & $\begin{array}{l}\text { O with breast symptoms referred to one } \\
\text { hospital between } 1996 \text { and } 1997\end{array}$ & $\begin{array}{l}\text { Multivariate } \\
\text { analysis }\end{array}$ \\
\hline$(56)$ & 2000 & $\begin{array}{l}\text { Thai- } \\
\text { land }\end{array}$ & $\begin{array}{l}\mathrm{PD}=\text { symptom discovery to }\left.\right|^{\text {st }} \text { consul- } \\
\text { tation. }(\mathrm{QV}: \mathrm{w}) \\
\mathrm{SD}=\mathrm{I}^{\text {st }} \text { medical consultation to hospi- } \\
\text { tal admission. }(\mathrm{QV}: \mathrm{w})\end{array}$ & $\begin{array}{l}\text { Structured interviews + } \\
\text { Medical records }\end{array}$ & 94 & $\begin{array}{l}\text { BC patients treated at the only university } \\
\text { hospital in the Southern Region of Thailand }\end{array}$ & $\begin{array}{l}\text { Multivariate } \\
\text { analysis }\end{array}$ \\
\hline$(75)$ & 2001 & UK & $\begin{array}{l}\text { Women's narratives about their } \\
\text { experiences from symptom discovery } \\
\text { to treatment. }\end{array}$ & Semistructured interviews & 46 & $\begin{array}{l}\mathrm{BC}+\text { diagnosed at one hospital in previous } \\
\text { two months }\end{array}$ & $\begin{array}{l}\text { Framework } \\
\text { method of } \\
\text { analysis. }\end{array}$ \\
\hline (69) & 2001 & $\begin{array}{l}\text { Nether- } \\
\text { lands }\end{array}$ & $\begin{array}{l}\text { Women's experiences from symptom } \\
\text { discovery to seeking for medical } \\
\text { attention. }\end{array}$ & In-depth interviews & 23 & $\begin{array}{l}\text { Patients with self-discovered cancer } \\
\text { symptoms (breast, melanoma, colon and } \\
\text { testicular) }\end{array}$ & $\begin{array}{l}\text { Andersen's PD } \\
\text { theory }\end{array}$ \\
\hline
\end{tabular}


(Continued)

\begin{tabular}{|c|c|c|c|c|c|c|c|}
\hline (79) & 2001 & $\begin{array}{l}\text { Nether- } \\
\text { lands }\end{array}$ & $\begin{array}{l}\text { Women's experiences from symptom } \\
\text { discovery to seeking for medical } \\
\text { attention. }\end{array}$ & In- depth interviews & 33 & $\begin{array}{l}23 \text { patients with self-discovered cancer } \\
\text { symptoms \& } 10 \text { General Practitioners }\end{array}$ & $\begin{array}{l}\text { Content } \\
\text { analysis }\end{array}$ \\
\hline$(32)$ & 2001 & Italy & $\begin{array}{l}\text { PD }=\text { symptom discovery to } I^{\text {st }} \text { consul- } \\
\text { tation. }(\geq I, \geq 3 \mathrm{~m}) \\
D D=I \text { st consultation to hospital } \\
\text { admission. }(\geq I, \geq 3 \mathrm{~m})\end{array}$ & Semistructured questionnaires & 644 & $\begin{array}{l}\text { o with operable BC, operated at the Natio- } \\
\text { nal Cancer Institute of Naples }\end{array}$ & $\begin{array}{l}\text { Multivariate } \\
\text { analysis }\end{array}$ \\
\hline (II) & 2002 & $\begin{array}{c}\text { Germa- } \\
\text { ny }\end{array}$ & $\begin{array}{l}\mathrm{PD}=\text { symptom discovery to } \mathrm{I}^{\text {st }} \text { consul- } \\
\text { tation. }(\mathrm{I}-3, \geq 3 \mathrm{~m})\end{array}$ & $\begin{array}{l}\text { VERDI study database + } \\
\text { Structured interviews }\end{array}$ & 380 & $\begin{array}{l}\text { Saarland region residents, with symptoma- } \\
\text { tic BC (1996-1998) }\end{array}$ & $\begin{array}{l}\text { Multivariate } \\
\text { analysis }\end{array}$ \\
\hline$(122)$ & 2002 & USA & $\begin{array}{l}\text { Self-reported likelihood of patient } \\
\text { delay= probability of patient delay for } \\
\text { BC symptoms. }\end{array}$ & $\begin{array}{l}\text { Self-administered questio- } \\
\text { nnaires }\end{array}$ & 699 & $\begin{array}{l}\text { Voluntary }+ \text { without cancer recruited in } \\
\text { communitarian organizations other than } \\
\text { health care services }\end{array}$ & $\begin{array}{l}\text { Multivariate } \\
\text { analysis }\end{array}$ \\
\hline$(91)$ & 2002 & USA & $\begin{array}{l}\mathrm{DD}=\text { physician action that completed } \\
\text { an episode of care without diagnosing } \\
\text { cancer of which there was a sign. }\end{array}$ & $\begin{array}{l}\text { Medical records of patients } \\
\text { seen by I surgeon (one of the } \\
\text { authors) }\end{array}$ & 454 & $\begin{array}{l}\text { BC patients referred to a single surgeon } \\
\text { (between } 1992 \text { and } 1999 \text { ( } 454 \text { cancers in } \\
436 \text { patients) }\end{array}$ & $\begin{array}{l}\text { Multivariate } \\
\text { analysis }\end{array}$ \\
\hline$(123)$ & 2003 & $\begin{array}{c}\text { Germa- } \\
\text { ny }\end{array}$ & $\begin{array}{l}S D=I^{\text {st }} \text { consultation to treatment. } \\
(I-3, \geq 3 \mathrm{~m})\end{array}$ & $\begin{array}{l}\text { VERDI study database + } \\
\text { Structured interviews }\end{array}$ & 380 & $\begin{array}{l}\text { Saarland region residents, with symptoma- } \\
\text { tic BC (1996-1998) }\end{array}$ & $\begin{array}{l}\text { Multivariate } \\
\text { analysis }\end{array}$ \\
\hline$(65)$ & 2003 & $\begin{array}{l}\text { Nether- } \\
\text { lands }\end{array}$ & $\begin{array}{l}\text { Intention to seek medical attention for } \\
\text { cancer symptoms. }\end{array}$ & $\begin{array}{l}\text { Postal self-administered } \\
\text { questionnaires }\end{array}$ & 534 & $\begin{array}{l}\text { Convenience sample: controls of a longitu- } \\
\text { dinal study of asymptomatic Dutch adults } \\
\text { recruited in } 1999\end{array}$ & $\begin{array}{l}\text { Multivariate } \\
\text { analysis }\end{array}$ \\
\hline$(74)$ & 2003 & $\begin{array}{l}\text { Hong } \\
\text { Kong }\end{array}$ & $\begin{array}{l}\text { Illness experience of } \mathrm{BC} \text { women from } \\
\text { symptom discovery to recovery. }\end{array}$ & Semistructured interviews & 17 & $\begin{array}{l}\text { Chinese } \text { i treated for non-metastatic BC in } \\
\text { one public breast medical center }\end{array}$ & $\begin{array}{l}\text { Phenomenologi- } \\
\text { cal analysis }\end{array}$ \\
\hline (6) & 2003 & UK & $\begin{array}{l}\mathrm{PD}=\text { symptom discovery to } \mathrm{I}^{\mathrm{st}} \\
\text { consultation. }\end{array}$ & $\begin{array}{l}\text { Semistructured interviews }+ \\
\text { focus groups }\end{array}$ & 33 & $\begin{array}{l}\text { Cancer patients diagnosed in previous } \\
\text { two years }\end{array}$ & $\begin{array}{l}\text { Content } \\
\text { analysis }\end{array}$ \\
\hline$(43)$ & 2003 & Iran & $\begin{array}{l}\mathrm{PD}=\text { symptom discovery to } \mathrm{I}^{\text {st }} \text { consul- } \\
\text { tation. }(>12 \mathrm{w})\end{array}$ & $\begin{array}{l}\text { Structured interviews + } \\
\text { Medical records }\end{array}$ & 190 & BC 9 treated at two hospitals in Tehran & $\begin{array}{l}\text { Multivariate } \\
\text { analysis }\end{array}$ \\
\hline$(55)$ & 2003 & Mexico & $\begin{array}{l}\text { Early Clinical Stage: women with BC } \\
\text { stage } I . \\
S D=I^{\text {st }} \text { consultation to beginning of } \\
\text { treatment. }(>3 \mathrm{~m})\end{array}$ & Structured interviews & 40 & $\begin{array}{l}\text { BC } 9 \text { treated at breast clinic. Cases: stage } \\
\text { I patients (I0); Controls: stage II, III \& IV } \\
\text { patients ( } 30)\end{array}$ & $\begin{array}{l}\text { Multivariate } \\
\text { analysis }\end{array}$ \\
\hline$(16)$ & 2004 & UK & $\begin{array}{l}\mathrm{DD}=\text { Ist medical consultation to final } \\
\mathrm{BC} \text { diagnosis. }(>2 \mathrm{~m})\end{array}$ & Medical records & 72 & $\begin{array}{l}\text { BC +with diagnosis delay seen at one } \\
\text { hospital (1988-1999) }\end{array}$ & $\begin{array}{l}\text { Bivariate } \\
\text { analysis }\end{array}$ \\
\hline$(92)$ & 2004 & $\begin{array}{l}\text { Nether- } \\
\text { lands }\end{array}$ & $\begin{array}{l}\mathrm{DD}=\text { abnormal screening mammogra- } \\
\text { phy to final } \mathrm{BC} \text { diagnosis. }(>3 \mathrm{~m})\end{array}$ & Medical records & 770 & $\begin{array}{l}\mathrm{BC}+\text { diagnosed after abnormal screening } \\
\text { mammogram at two units of national } \\
\text { screening program }\end{array}$ & $\begin{array}{l}\text { Bivariate } \\
\text { analysis }\end{array}$ \\
\hline$(17)$ & 2004 & USA & $\begin{array}{l}S D=\left.\right|^{\text {st }} \text { medical consultation to } \\
\text { treatment. }\end{array}$ & $\begin{array}{l}\text { Structured interviews + } \\
\text { Medical records }\end{array}$ & 831 & $\begin{array}{l}\mathrm{BC}+\text {, residents of Atlanta. ( } 25 \text { I African- } \\
\text { Americans \& } 580 \text { whites) }\end{array}$ & $\begin{array}{l}\text { Multivariate } \\
\text { analysis }\end{array}$ \\
\hline$(87)$ & 2004 & UK & $\begin{array}{l}S D=I^{\text {st }} \text { medical consultation to } \\
\text { treatment. }\end{array}$ & Medical records & 1097 & $\begin{array}{l}\text { BC o identified through Scottish Cancer } \\
\text { Registry (1997-1998) }\end{array}$ & $\begin{array}{l}\text { Multivariate } \\
\text { analysis }\end{array}$ \\
\hline$(50)$ & 2004 & Norway & $\begin{array}{l}P D=\text { Definition not specified. } \\
(\geq 1 \mathrm{~m})\end{array}$ & $\begin{array}{l}\text { Semistructured interviews + } \\
\text { psychological tests }\end{array}$ & 96 & BC + stages I \& II treated at one hospital & $\begin{array}{l}\text { Multivariate } \\
\text { analysis }\end{array}$ \\
\hline$(12)$ & 2005 & Iran & $\begin{array}{l}\mathrm{PD}=\text { symptom discovery to } \mathrm{I}^{\text {st }} \text { consul- } \\
\text { tation. }(>\mathrm{I} \mathrm{m})\end{array}$ & Structured interviews & 200 & $\begin{array}{l}\text { BC + with stage IIB, III or IV seen at refe- } \\
\text { rral hospital of Tehran. }\end{array}$ & $\begin{array}{l}\text { Bivariate } \\
\text { analysis }\end{array}$ \\
\hline$(83)$ & 2005 & USA & $\begin{array}{l}\text { Medical seeking behavior of women } \\
\text { who experienced breast symptoms. }\end{array}$ & In depth interviews & II & $\begin{array}{l}\text { i with previous experiences of breast } \\
\text { symptoms }\end{array}$ & $\begin{array}{l}\text { Heuristic } \\
\text { analysis }\end{array}$ \\
\hline$(81)$ & 2005 & USA & $\begin{array}{l}\text { Locally advanced } B C=\text { clinical stages III } \\
\text { and IV at arrival to } 3^{\text {rd }} \text { level hospital. }\end{array}$ & $\begin{array}{l}\text { Semistructured interviews + } \\
\text { psychological tests }\end{array}$ & 35 & $\begin{array}{l}\text { BC + seen at university hospital. (II early } \\
\text { stage \& I I late stage); \& I } 3 \text { patients' } \\
\text { husbands }\end{array}$ & $\begin{array}{l}\text { Descriptive } \\
\text { analysis }\end{array}$ \\
\hline (5) & 2005 & UK & $P D=$ Definition not specified & $\begin{array}{l}\text { Self-administered postal } \\
\text { questionnaires }\end{array}$ & 65192 & $\begin{array}{l}\text { Cancer patients (data extracted from } 1999 \\
-2000 \text { National Survey of NHS Patients) }\end{array}$ & $\begin{array}{l}\text { Multivariate } \\
\text { analysis }\end{array}$ \\
\hline$(59)$ & 2005 & UK & $\begin{array}{l}\text { Cancer patients' experiences from } \\
\text { symptom discovery to }\left.\right|^{\text {st }} \text { medical } \\
\text { consultation. }\end{array}$ & Meta-synthesis & 32 & $\begin{array}{l}\text { Qualitative studies related to cancer help } \\
\text { seeking experience, published in English } \\
\text { between } 1985 \& 2004\end{array}$ & Meta-synthesis \\
\hline$(97)$ & 2006 & Canada & $\begin{array}{l}\text { Patient perceptions of impeding and } \\
\text { facilitating events in cancer care } \\
\text { continuum. }\end{array}$ & $\begin{array}{l}\text { Structured questionnaire }+ \\
\text { semistructured interview }\end{array}$ & 120 & $\begin{array}{l}\text { \& with } B C \text { receiving adjuvant radiotherapy } \\
\text { between } 2002 \& 2003 \text { at a university } \\
\text { hospital }\end{array}$ & $\begin{array}{l}\text { Content analy- } \\
\text { sis. Andersen's } \\
\text { PD theory }\end{array}$ \\
\hline$(39)$ & 2006 & UK & $\begin{array}{l}\text { PD = symptom discovery to } I^{\text {st }} \text { medi- } \\
\text { cal consultation. }(\geq 12 \mathrm{w})\end{array}$ & Semistructured interviews & 69 & $\begin{array}{l}\text { Consecutive series of } 100_{-} \geq 65 \text { years old } \\
\text { with } \mathrm{BC} \text { diagnosed between } 2002 \text { and } 2003 \\
\text { in two London hospitals }\end{array}$ & $\begin{array}{l}\text { Quant:biva- } \\
\text { riate/ Qual: } \\
\text { framework } \\
\text { method }\end{array}$ \\
\hline$(76)$ & 2006 & USA & $\begin{array}{l}\text { PD }=\text { symptom discovery to }\left.\right|^{\text {st }} \text { medical } \\
\text { consultation. }(\geq 3 \mathrm{~m})\end{array}$ & In-depth interviews & 28 & $\begin{array}{l}\text { Voluntary }+ \text { with breast symptoms recrui- } \\
\text { ted in community organizations other than } \\
\text { health care services }\end{array}$ & $\begin{array}{l}\text { Heuristic } \\
\text { analysis }\end{array}$ \\
\hline$(98)$ & 2007 & Canada & $\begin{array}{l}\text { Women's descriptions of path--ways } \\
\text { from detection of breast abnormality } \\
\text { to treatment. }\end{array}$ & Semistructured interviews & 35 & q recently operated for symptomatic $B C$ & $\begin{array}{l}\text { Critical ethno- } \\
\text { graphy }\end{array}$ \\
\hline
\end{tabular}

(Continues...) 


\begin{tabular}{|c|c|c|c|c|c|c|c|}
\hline$(90)$ & 2007 & Canada & $\begin{array}{l}\mathrm{DD}=\mathrm{I}^{\text {st }} \text { diagnostic procedure to final } \\
\mathrm{BC} \text { diagnosis. }(>5 \mathrm{w})\end{array}$ & $\begin{array}{l}\text { Structured interviews + } \\
\text { Medical records }\end{array}$ & 696 & $\begin{array}{l}\text { } \text { with } \mathrm{BC} \text { stages I, II and III who were } \\
\text { receiving treatment }\end{array}$ & $\begin{array}{l}\text { Multivariate } \\
\text { analysis }\end{array}$ \\
\hline (58) & 2007 & $\begin{array}{l}\text { Colom- } \\
\text { bia }\end{array}$ & $\begin{array}{l}\text { Advanced } \mathrm{BC}=\text { clinical stages III and IV } \\
\text { at diagnosis. }\end{array}$ & $\begin{array}{l}\text { Semistructured interviews } \\
+ \text { self-administered ques- } \\
\text { tionnaires }\end{array}$ & 102 & $\begin{array}{l}\text { Cases: advanced BC. } \\
\text { Controls: early BC (stage I \& II) }\end{array}$ & $\begin{array}{l}\text { Multivariate } \\
\text { analysis }\end{array}$ \\
\hline \multirow{3}{*}{ (7) } & \multirow{3}{*}{2008} & \multirow{3}{*}{$\begin{array}{l}\text { Den- } \\
\text { mark }\end{array}$} & $\begin{array}{l}\mathrm{PD}=\text { symptom discovery to }\left.\right|^{\text {st }} \\
\text { consultation. }\end{array}$ & \multirow{3}{*}{$\begin{array}{l}\text { Self-administered postal } \\
\text { questionnaires answe- } \\
\text { red by: GPs (medical } \\
\text { care events) \& Patients } \\
\text { (socioeconomic data) }\end{array}$} & \multirow{3}{*}{1892} & \multirow{3}{*}{$\begin{array}{l}\text { Cancer patients residents of Aarhus } \\
\text { County, identified through County Health } \\
\text { Service Registry (2004 -2005) } \\
\text { (29I BC cases) }\end{array}$} & \multirow{3}{*}{$\begin{array}{l}\text { Multivariate } \\
\text { analysis }\end{array}$} \\
\hline & & & $\begin{array}{l}\mathrm{DD}=\left.\right|^{\text {st }} \text { medical consultation to }\left.\right|^{\mathrm{st}} \\
\text { procedure of diagnosis. }\end{array}$ & & & & \\
\hline & & & $\begin{array}{l}\mathrm{SD}=1^{\text {st }} \text { procedure of diagnosis to } \\
\text { beginning of treatment. }\end{array}$ & & & & \\
\hline (33) & 2008 & Spain & $\begin{array}{l}\text { Interval from diagnosis to treatment= } \\
\left.\right|^{\text {st }} \text { diagnostic test to beginning of } \\
\text { treatment. }\end{array}$ & Medical records & 1023 & $\begin{array}{l}\text { Cancer patients diagnosed in } 22 \text { public } \\
\text { hospitals of Barcelona } \\
\text { ( } 266 \mathrm{BC} \text { cases) }\end{array}$ & $\begin{array}{l}\text { Multivariate } \\
\text { analysis }\end{array}$ \\
\hline \multicolumn{8}{|c|}{ Unger-Saldaña K \& Infante-Castañeda C, 2008} \\
\hline \multicolumn{8}{|c|}{$\begin{array}{l}\text { White rows: quantitative studies; gray rows: qualitative studies. } \mathrm{Abbreviations:} \mathrm{BC}=\text { breast cancer; } \mathrm{NS}=\text { not specified, } \mathrm{TD}=\text { total delay, } \mathrm{PD}=\text { patient delay, } \mathrm{SD}=\text { system delay or pro- } \\
\text { vider delay, } \mathrm{DD}=\text { diagnosis delay, } \mathrm{GPD}=\text { general practitioner delay, } \mathrm{RD}=\text { referral delay, } \mathrm{TD}=\text { treatment delay, } \mathrm{HD}=\text { hospital delay; } \mathrm{d}=\mathrm{days}, \mathrm{w}=\text { weeks, } \mathrm{m}=\mathrm{months}, \mathrm{QV}=\mathrm{quantitative} \\
\text { variable (where not specified delay was given categorical values which are indicated in parenthesis). }\end{array}$} \\
\hline \multicolumn{8}{|c|}{$\begin{array}{l}\text { Information in this column refers to type of analysis used to conclude regarding the association between delay and factors listed in Tables II and III. Some studies might have included } \\
\text { additional types of analysis for other variables } \\
\text { }=\text { women }\end{array}$} \\
\hline
\end{tabular}

4) The use of clinical records and population registries has the limitation of the quality of information and that only the available data can be used. Furthermore, delay has been shown to be underestimated when calculated based on information obtained from medical records; ${ }^{94} 5$ ) The lack of validation of instruments that measure delay is a problem common to most studies; and 6) Operational definitions used differ tremendously (Table IV) and this impedes comparison of results and meta-analysis that allow for more valid conclusions about the relationship between different factors and delay.

Among the qualitative studies reviewed, the most common flaw was the absence of theoretical analyses. The majority are merely descriptive. Nevertheless, there are interesting studies where different theories are used in an attempt to explain the reasoning of women who delay seeking medical attention. Most of them use psychological theories: psychoanalysis, ${ }^{67,80}$ Leventhal's self-regulation theory, ${ }^{96}$ Leventhal's theory of fear and danger control, ${ }^{69}$ Ajzen's theory of planned behavior, ${ }^{96}$ Gollwitzer's theory of implementation of intentions, ${ }^{96}$ Merton \& Kitt's theory of reference group behavior, ${ }^{68}$ Andersen \& Cacioppo's theory of total patient delay ${ }^{69,97}$ and heuristic analysis. ${ }^{73,83}$ Among the social theories that have been used are Beck \& Rosenstock's health belief model ${ }^{69}$ Bordieu's social capital theory ${ }^{98}$ and anthropological theories related to meaning construction such as those developed by Taylor, Lipowski and Kleinman. ${ }^{74}$

\section{Breast cancer delayed medical attention in Mexico}

Even though in Mexico about $50 \%$ of breast cancer patients are diagnosed at stages III and $\mathrm{IV}^{99}{ }^{99}$ research on the reasons behind delayed medical attention of breast cancer is practically non-existent. Only one published study done in Mexico was found, ${ }^{55}$ with several methodological limitations. It was done in Mexico City, in a military health services clinic that offers specialized services for women. It included only 40 patients, among which there was patient delay in $14(35 \%)$ and provider delay greater than three months in $21(52.5 \%)$. This study reports the association of certain factors with clinical stage, which was considered as the dependent variable that reflected delay. It was interesting that they considered indicators of accessibility but the small sample size did not allow for significant findings.

We currently have preliminary results of a research project that aims to measure and explain patient and provider delay of women seen in several hospitals in Mexico City. The first phase is qualitative, based on in-depth interviews of women with symptoms highly suggestive of breast cancer who arrive for the first time to the Breast Tumors Department of the Mexican National Cancer Institute. This institution is a concentration hospital that offers specialized cancer care for uninsured patients. The initial results of this study phase show that 
the most determinant factors in the conformation of different help seeking trajectories are women's socio-cultural characteristics, especially poverty, characteristics of their social networks, the kinds of social support they are able to get, accessibility to health services and medical errors in primary and secondary levels of care. ${ }^{100}$

\section{Directions for future research in developing countries}

Mortality rates for breast cancer have been steadily decreasing by 1-2\% per year since the 1990s in Europe and the United States of America, ${ }^{101}$ which has been attributed mainly to screening mammography and improvements in systemic therapy ${ }^{102}$ In contrast, in resource-limited countries, breast cancer mortality rates have remained the same. ${ }^{101}$ Some of the barriers to improve medical care for breast cancer in underdeveloped countries are lack of cancer knowledge among the general population, socioeconomic and cultural barriers, health service organizational problems, and resource constraints, ${ }^{103}$ as well as low quality of health services frequently used by people with low SES who lack formal employment, economic stability and health insurance. Improvements accomplished in breast cancer mortality rates in developed countries are most likely a consequence of a combination of scientific research, increased population awareness of the problem and political will. In the end, a health system is not only the Ministry of Health or the personal medical services offered, but the collection of social subsystems that interact to comprise it. ${ }^{104}$

In many LMC, including most of Latin American countries, emphasis in breast cancer policies and programs is currently being directed towards screening mammography, ${ }^{105}$ despite the fact that it is still controversial as to whether it does "more good than harm." ${ }^{106}$ Moreover, establishing a national screening program implies not only the cost of mammography equipment but also its equitable distribution as well as training and distribution of technical personnel for its execution and interpretation. Making this great expenditure on the availability of a screening test -of which the impact on mortality is still controversial- in countries where universal supply of accessible and high quality health services for breast cancer is still not available seems unfounded. Before developing mammography screening programs, efforts should be directed to develop and implement appropriate treat- ment guidelines and provide access to diagnostic and treatment services. ${ }^{105,107}$

In Mexico, treatment expenditures for many previously uninsured women with breast cancer have been covered since $2007^{108}$ thanks to the creation of the program "Seguro Popular de Salud" (Popular Health Insurance). This is a program that subsidizes an explicit system of health interventions financed with contributions by federal and state governments and by affiliated families. ${ }^{109}$ While recognizing this as a very relevant effort to overcome treatment coverage problems that existed for this population, there are still multiple barriers that impede breast cancer patients to be timely diagnosed and treated.

Identification of factors related to delay of diagnosis and treatment in the context of underdeveloped countries, including Mexico, is greatly needed. Only five of the breast cancer delay studies reviewed were done in developing countries: Thailand, Iran, Colombia and Mexico. The study of breast cancer delay considering specific socio-cultural and health systems characteristics would allow for the identification of specific factors toward which interventions should be directed. Many of these factors are difficult to modify since they are cultural or at the society's structural level; the challenge we face is finding modifiable mechanisms that can improve early medical attention of breast cancer in each country.

\section{Conclusion}

This paper identifies knowledge gaps and methodological inconsistencies found in international publications of breast cancer delay. Our purpose was to facilitate the identification of the most pressing research needs on the matter. There is a need for more comprehensive research that takes into account socio-structural and health services factors. Furthermore, research on delay should aim to identify locally modifiable factors in underdeveloped countries towards which equity oriented political programs can be directed to improve medical attention for breast cancer so that mortality rates can be reduced and patients' quality of life improved.

\section{Acknowledgements}

This study was supported by a grant from CONACYT/ SSA/IMSS/ISSSTE SALUD-2007-C01-69439. We thank Franz G. Pruefer for critically reviewing the paper. 


\section{References}

I. Porter P."Westernizing” women's risks? Breast cancer in lower-income countries. N Engl J Med 2008;358(3):2I3-6.

2. McCoy CB, Pereyra M, Metsch LR, Collado-Mesa F, Messiah SE, Sears S.A community-based breast cancer screening program for medically underserved women: its effect on disease stage at diagnosis and on hazard of death. Rev Panam Salud Publica 2004;15(3):160-7.

3. Committee on Cancer Control in Low and Middle Income Countries Board on Global Health. The Cancer Burden in Low and Middle Income Countries and How It Is Measured. In: Sloan FA, Gelband H, editors. Cancer Control Opportunities in Low and Middle Income Countries. Washington, D.C.:The National Academies Press; 2007.

4. Samet JM, Hunt WC, Lerchen ML, Goodwin JS. Delay in seeking care for cancer symptoms: a population-based study of elderly New Mexicans.J Natl Cancer Inst 1988;80(6):432-8.

5. Neal RD,AllgarVL. Sociodemographic factors and delays in the diagnosis of six cancers: analysis of data from the "National Survey of NHS Patients: Cancer". Br J Cancer 2005;92( I I): 1 97I-5.

6. Leydon GM, Bynoe-Sutherland J, Coleman MP.The journey towards a cancer diagnosis: the experiences of people with cancer, their family and carers. Eur J Cancer Care (Engl) 2003; |2(4):3 17-26.

7. Hansen RP, Olesen F, Sorensen HT, Sokolowski I, Sondergaard J.

Socioeconomic patient characteristics predict delay in cancer diagnosis: a Danish cohort study. BMC Health Serv Res 2008;8:49.

8. Richards MA, Westcombe AM, Love SB, Littlejohns P, Ramirez AJ. Influence of delay on survival in patients with breast cancer: a systematic review. Lancet 1999;353(9159): I | 19-26.

9. Aronowitz RA. Do not delay: breast cancer and time, 1900-1970. Milbank Q 200I;79(3):355-86.

10. HalstedWS. I.The Results of Radical Operations for the Cure of Carcinoma of the Breast. Ann Surg 1907;46(I): I- 19.

II. Arndt V, Sturmer T, Stegmaier C, Ziegler H, Dhom G, Brenner H. Patient delay and stage of diagnosis among breast cancer patients in Germany-a population based study. Br J Cancer 2002;86(7):1034-40.

12. Harirchi I, Ghaemmaghami F, Karbakhsh M, Moghimi R, Mazaherie H.

Patient delay in women presenting with advanced breast cancer: an Iranian study. Public Health 2005; I 19(10):885-91.

13. Pack GT, Gallo JS. The culpability for delay in the treatment of cancer. Am J Cancer 1938;33:443-462.

14. Caplan LS, May DS, Richardson LC. Time to diagnosis and treatment of breast cancer: results from the National Breast and Cervical Cancer Early Detection Program, 1991-1995. Am J Public Health 2000;90(I):130-4.

15. Tartter PI, Pace D, Frost M, Bernstein JL. Delay in diagnosis of breast cancer.Ann Surg 1999;229(I):91-6.

16. Barber MD, Jack W, Dixon JM. Diagnostic delay in breast cancer. Br J Surg 2004;9I(I):49-53.

17. Gwyn K, Bondy ML, Cohen DS, Lund MJ, Liff JM, Flagg EW, et al. Racial differences in diagnosis, treatment, and clinical delays in a populationbased study of patients with newly diagnosed breast carcinoma. Cancer 2004;100(8):1595-604.

18. MacArthur C, Smith A. Delay in breast cancer and the nature of presenting symptoms. Lancet I98I; I(8220 Pt I):60I-3.

19. Sainsbury R, Johnston C, Haward B. Effect on survival of delays in referral of patients with breast-cancer symptoms: a retrospective analysis. Lancet 1999;353(9159): I I32-5.

20. Higginson J. Patient delay with reference to stage of cancer. Cancer 1962;15:50-6.

21. Feldman JG, Saunders M, Carter AC, Gardner B. The effects of patient delay and symptoms other than a lump on survival in breast cancer. Cancer 1983;5I(7): I226-9.
22. Robinson E, Mohilever J, Zidan J, Sapir D. Delay in diagnosis of cancer. Possible effects on the stage of disease and survival. Cancer 1984;54(7): 1454-60.

23. Vernon SW, Tilley BC, Neale AV, Steinfeldt L. Ethnicity, survival, and delay in seeking treatment for symptoms of breast cancer. Cancer 1985;55(7): 1563-7|.

24. Afzelius P, Zedeler K, Sommer H, Mouridsen HT, Blichert-Toft M. Patient's and doctor's delay in primary breast cancer. Prognostic implications. Acta Oncol 1994;33(4):345-5I.

25. Charlson ME. Delay in the treatment of carcinoma of the breast. Surg Gynecol Obstet 1985;160(5):393-9.

26. Rossi S, Cinini C, Di Pietro C, Lombardi CP, Crucitti A, Bellantone R, et al. Diagnostic delay in breast cancer: correlation with disease stage and prognosis. Tumori 1990;76(6):559-62.

27. Richards MA, Smith P, Ramirez AJ, Fentiman IS, Rubens RD. The influence on survival of delay in the presentation and treatment of symptomatic breast cancer. $\mathrm{Br} J$ Cancer 1999;79(5-6):858-64.

28. Elwood JM, Moorehead WP. Delay in diagnosis and long-term survival in breast cancer. Br Med J 1980;280(6227): 1291-4.

29. Gregorio DI, Cummings KM, Michalek A. Delay, stage of disease, and survival among White and Black women with breast cancer. Am J Public Health 1983;73(5):590-3.

30. Robbins GF, Bross I.The significance of delay in relation to prognosis of patients with primary operable breast cancer. Cancer 1957;10(2):338-44. 31. Dennis CR, Gardner B, Lim B. Analysis of survival and recurrence vs. patient and doctor delay in treatment of breast cancer. Cancer 1975;35(3):7|4-20.

32. Montella M, Crispo A, D'Aiuto G, De Marco M, de Bellis G, Fabbrocini $\mathrm{G}$, et al. Determinant factors for diagnostic delay in operable breast cancer patients. Eur J Cancer Prev 200I; I0(I):53-9.

33. Perez G, Porta M, Borrell C, Casamitjana M, Bonfill X, Bolibar I, et al. Interval from diagnosis to treatment onset for six major cancers in Catalonia, Spain. Cancer Detect Prev 2008;32(3):267-75.

34. Hellman S. Karnofsky Memorial Lecture. Natural history of small breast cancers.J Clin Oncol 1994;12(10):2229-34.

35. Husemann Y, Geigl JB, Schubert F, Musiani P, Meyer M, Burghart E, et al. Systemic spread is an early step in breast cancer. Cancer Cell 2008; I3(I):58-68.

36. Boyd NF, Meakin JW, Hayward JL, Brown TC. Clinical estimation of the growth rate of breast cancer. Cancer 1981;48(4): 1037-42.

37. Gore S, Langlands A, Pocock S, Kerr G. Natural history of breast cancer. Recent Results Cancer Res 1982;80:134-4I.

38. Punglia RS, Morrow M, Winer EP, Harris JR. Local therapy and survival in breast cancer. N Engl J Med 2007;356(23):2399-405.

39. Burgess CC, Potts HW, Hamed H, Bish AM, Hunter MS, Richards MA, et al. Why do older women delay presentation with breast cancer symptoms? Psychooncology 2006; I5(II):962-8.

40. GIVIO (Interdisciplinary Group for Cancer Care Evaluation) Italy. Reducing diagnostic delay in breast cancer. Possible therapeutic implications. . Cancer 1986;58(8): 1756-61.

4I. Burgess CC, Ramirez AJ, Richards MA, Love SB. Who and what influences delayed presentation in breast cancer? $\mathrm{Br} J$ Cancer 1998;77(8):1343-8.

42. Samet JM, Hunt WC, Goodwin JS. Determinants of cancer stage. A population-based study of elderly New Mexicans. Cancer 1990;66(6):1302-7.

43. Montazeri A, Ebrahimi M, Mehrdad N,Ansari M, Sajadian A. Delayed presentation in breast cancer: a study in Iranian women. BMCWomens Health 2003;3(I):4.

44. Hardin C, Pommier S, Pommier RF.The relationships among clinician delay of diagnosis of breast cancer and tumor size, nodal status, and stage. Am J Surg 2006; 192(4):506-8. 
45. Arndt V, Sturmer T, Stegmaier C, Ziegler H, Dhom G, Brenner H. Socio-demographic factors, health behavior and late-stage diagnosis of breast cancer in Germany: a population-based study.J Clin Epidemiol 200I;54(7):719-27.

46. Huguley CM, Jr., Brown RL, Greenberg RS, ClarkWS. Breast selfexamination and survival from breast cancer. Cancer 1988;62(7): I389-96. 47. Carter CL,Allen C, Henson DE. Relation of tumor size, lymph node status, and survival in 24,740 breast cancer cases. Cancer 1989;63(I): I8I-7. 48. Fisher ER, Redmond C, Fisher B.A perspective concerning the relation of duration of symptoms to treatment failure in patients with breast cancer. Cancer 1977;40(6):3160-7.

49. Olivotto IA, Gomi A, Bancej C, Brisson J, Tonita J, Kan L, et al. Influence of delay to diagnosis on prognostic indicators of screen-detected breast carcinoma. Cancer 2002;94(8):2143-50.

50.Tjemsland L, Soreide JA. Operable breast cancer patients with diagnostic delay-oncological and emotional characteristics. Eur J Surg Oncol 2004;30(7):72I-7.

5I. Mann BD, Giuliano AE, Bassett LW, Barber MS, Hallauer W, Morton DL. Delayed diagnosis of breast cancer as a result of normal mammograms. Arch Surg 1983; I 18(I):23-4.

52. Langlands AO, Gebski V, Hirsch D, Tattersall MH. Delay in the clinical diagnosis of breast cancer: estimating its effect on prognosis, with particular reference to medical litigation. Breast 2002; I (5):386-93. 53.Turner J, Kelly B, Swanson C,Allison R, Wetzig N. Psychosocial impact of newly diagnosed advanced breast cancer. Psychooncology 2005; 14(5):396-407.

54. Ramirez AJ,Westcombe AM, Burgess CC, Sutton S, Littlejohns P, Richards MA. Factors predicting delayed presentation of symptomatic breast cancer: a systematic review. Lancet 1999;353(9159): I I27-3 I. 55. Rodríguez Ríos M, Uscanga Sánchez R, Gutiérrez Vega P, GA JG. Factores asociados a la oportunidad en el diagnóstico de cáncer de mama. Rev Sanid Milit Mex 2003;57(5):29I-298.

56. Thongsuksai P, Chongsuvivatwong V, Sriplung H. Delay in breast cancer care: a study in Thai women. Med Care 2000;38(I): 108-14.

57. Nosarti C, Crayford T, Roberts JV, Elias E, McKenzie K, David AS. Delay in presentation of symptomatic referrals to a breast clinic: patient and system factors. Br J Cancer 2000;82(3):742-8.

58. Wiesner C. Determinantes psicológicos, clínicos y sociales del diagnóstico temprano del cáncer de mama en Bogotá, Colombia. Rev Colomb Cancerol 2007; I ( I):13-22.

59. Smith LK, Pope C, Botha JL. Patients' help-seeking experiences and delay in cancer presentation: a qualitative synthesis. Lancet 2005;366(9488):825-31.

60. Waxman BD, Fitts WT, Jr. Survival of female patients with cancer of the breast: a study of the effects of demographic and economic factors. Am J Surg 1959;97(I):31-5.

6I. Lannin DR, Mathews HF, Mitchell J, Swanson MS, Swanson FH, Edwards MS. Influence of socioeconomic and cultural factors on racial differences in late-stage presentation of breast cancer.JAMA 1998;279(22):I80I-7. 62. Richardson JL, Langholz B, Bernstein L, Burciaga C, Danley K, Ross RK. Stage and delay in breast cancer diagnosis by race, socioeconomic status, age and year. Br J Cancer 1992;65(6):922-6.

63. Coates RJ, Bransfield DD, Wesley M, Hankey B, Eley JW, Greenberg $R S$, et al. Differences between black and white women with breast cancer in time from symptom recognition to medical consultation. Black/White Cancer Survival Study Group. J Natl Cancer Inst 1992;84(I2):938-50. 64. Lynch J, Kaplan G. Socioeconomic Position. In: Berkman LF, Kawachi I, editors. Social Epidemiology. New York: Oxford University Press; 2000. 65. De Nooijer J, Lechner L, de Vries H. Social psychological correlates of paying attention to cancer symptoms and seeking medical help. Soc Sci Med 2003;56(5):915-20.

66. Aitken-Swan J, Paterson R. The cancer patient: delay in seeking advice. $\mathrm{Br}$ Med J 1955; I (49|4):623-7.
67. Gold MA. Causes of Patients' Delay in Diseases of the Breast. Cancer 1964;17:564-77.

68. Cobb B, Clark RL,Jr., Mc GC, Howe CD. Patient-responsible delay of treatment in cancer; a social psychological study. Cancer 1954;7(5):920-6. 69. de Nooijer J, Lechner L, de Vries H.A qualitative study on detecting cancer symptoms and seeking medical help; an application of Andersen's model of total patient delay. Patient Educ Couns 200I;42(2): I45-57. 70. Robbins GF, Macdonald MC, Pack GT. Delay in the diagnosis and treatment of physicians with cancer. Cancer 1953;6(3):624-6. 71. Buttlar CA, Templeton AC. The size of breast masses at presentation. The impact of prior medical training. Cancer 1983;5 (9): 1750-3. 72. Kapiga SH, Lwihula GK, Shao JF, Hunter DJ. Predictors of AIDS knowledge, condom use and high-risk sexual behaviour among women in Dar-es-Salaam, Tanzania. Int J STD AIDS 1995;6(3): I75-83.

73. Sivagnanam G, Namasivayam K, Rajasekaran M,Thirumalaikolundusubr amanian P, Ravindranath C.A comparative study of the knowledge, beliefs, and practices of diabetic patients cared for at a teaching hospital (free service) and those cared for by private practitioners (paid service). Ann N Y Acad Sci 2002;958:416-9.

74. Lam WW, Fielding R. The evolving experience of illness for Chinese women with breast cancer: a qualitative study. Psychooncology 2003; 12(2):127-40.

75. Burgess C, Hunter MS, Ramirez AJ.A qualitative study of delay among women reporting symptoms of breast cancer. $\mathrm{Br} J$ Gen Pract 200I;5I (473):967-7I.

76. Facione NC, Facione PA. The cognitive structuring of patient delay in breast cancer. Soc Sci Med 2006;63(I2):3 I37-49.

77. Lauver D, Coyle M, Panchmatia B.Women's reasons for and barriers to seeking care for breast cancer symptoms. Womens Health Issues 1995;5(I):27-35.

78. Facione NC, Giancarlo CA. Narratives of breast symptom discovery and cancer diagnosis: psychologic risk for advanced cancer at diagnosis. Cancer Nurs 1998;21(6):430-40.

79. De Nooijer J, Lechner L, DeVries H. Help-seeking behaviour for cancer symptoms: perceptions of patients and general practitioners. Psychooncology 200I; I0(6):469-78.

80. Shands HC, Finesinger JE, Cobb S, Abrams RD. Psychological mechanisms in patients with cancer. Cancer 1951;4(6): I I59-70. 8I. Mohamed IE, Skeel Williams K, Tamburrino M,Wryobeck J, Carter S. Understanding locally advanced breast cancer: what influences a woman's decision to delay treatment? Prev Med 2005;4I (2):399-405.

82. Facione NC, Giancarlo C, Chan L. Perceived risk and help-seeking behavior for breast cancer.A Chinese-American perspective. Cancer Nurs 2000;23(4):258-67.

83. Katapodi MC, Facione NC, Humphreys JC, Dodd MJ. Perceived breast cancer risk: heuristic reasoning and search for a dominance structure. Soc Sci Med 2005;60(2):42I-32.

84. Facione NC. Perceived risk of breast cancer: influence of heuristic thinking. Cancer Pract 2002;10(5):256-62.

85. Grunfeld EA, Ramirez AJ, Hunter MS, Richards MA.Women's knowledge and beliefs regarding breast cancer. $\mathrm{Br} J$ Cancer 2002;86(9): 1373-8.

86. Pfeiffer D. The conceptualization of disability. In: Barnartt SN, Altman BM, editors. Exploring Theories and Explaining Methodologies: where are we and where we need to go. Oxford, UK: Elsevier Science Ltd.; 2001. 87. Robertson R, Campbell NC, Smith S, Donnan PT, Sullivan F, Duffy R, et al. Factors influencing time from presentation to treatment of colorectal and breast cancer in urban and rural areas. Br J Cancer 2004;90(8): 1479-85. 88. Jenner DC, Middleton A,Webb WM, Oommen R, Bates T. In-hospital delay in the diagnosis of breast cancer. Br J Surg 2000;87(7):914-9.

89. Caplan LS, Helzlsouer KJ, Shapiro S, Wesley MN, Edwards BK. Reasons for delay in breast cancer diagnosis. Prev Med 1996;25(2):218-24. 
90. Bairati I, Jobin E, Fillion L, Larochelle M,Vincent L. Determinants of delay for breast cancer diagnosis. Cancer Detect Prev 2007;3I (4):323-3I. 91. Goodson WH, 3rd, Moore DH, 2nd. Causes of physician delay in the diagnosis of breast cancer. Arch Intern Med 2002;162(I2):1343-8. 92. Duijm LE, Groenewoud JH, Jansen FH, Fracheboud J, van Beek M, de Koning HJ. Mammography screening in the Netherlands: delay in the diagnosis of breast cancer after breast cancer screening. $\mathrm{Br} J$ Cancer 2004;91(10): 1795-9.

93. Infante-Castañeda C. Bridging the system's gap between interprofessional care and patient safety: Sociological insights. Journal of Interprofessional Care 2006;20(5):517-525.

94. Porta M, Malats N, Belloc J, Gallen M, Fernandez E. Do we believe what patients say about their neoplastic symptoms? An analysis of factors that influence the interviewer's judgement. Eur J Epidemiol 1996;12(6):553-62. 95. Neal RD, Pasterfield D, Wilkinson C, Hood K, Makin M, Lawrence H. Determining patient and primary care delay in the diagnosis of cancer lessons from a pilot study of patients referred for suspected cancer. BMC Fam Pract 2008:9:9.

96. Bish A, Ramirez A, Burgess C, Hunter M. Understanding why women delay in seeking help for breast cancer symptoms.J Psychosom Res 2005;58(4):321-6

97. Bairati I, Fillion L, Meyer FA, Hery C, Larochelle M.Women's perceptions of events impeding or facilitating the detection, investigation and treatment of breast cancer. Eur J Cancer Care (Engl) 2006; 15(2): 183-93.

98. Angus J, Paszat L, McKeever P,Trebilock A, Shivji F, Edwards B. Pathways to Breast Cancer Diagnosis and Treatment: Exploring the Social Relations of Diagnostic Delay. Texto Contexto Enferm 2007;16(4):59I-598.

99. Cárdenas-Sánchez J, Sandoval-Guerrero F. Segunda Revisión del Consenso Nacional sobre el diagnóstico y tratamiento del Cáncer Mamario, México 2005. Gaceta Mexicana de Oncología 2006;5(S2). 100. Unger-Saldaña K, Infante-Castañeda C. Delayed Medical Attention of Breast Cancer in Mexican Women [Congress Abstract]. In: International Union Against Cancer UICC 2008World Cancer Congress "Towards true cancer control". Geneva, Switzerland: UICC; 2008.

I0I. Masood S. Coming together to conquer the fight against breast cancer in countries of limited resources: the challenges and the opportunities. Breast J 2007; 13(3):223-5.

102. Jones AL. Reduction in mortality from breast cancer. BMJ 2005;330(7485):205-6.

103. Anderson BO, Shyyan R, Eniu A, Smith RA, Yip CH, Bese NS, et al. Breast cancer in limited-resource countries: an overview of the Breast Health Global Initiative 2005 guidelines. Breast J 2006; I2 Suppl I:S3- I5. 104. Varkevisser CM, Pathmanathan I, Brownlee A. Designing and conducting health systems research projects, data analysis and report writing. (Section 2.3). In: IDRC/WHO Ottawa, Canada; 2003.

105. Robles SC, Galanis E. Breast cancer in Latin America and the Caribbean. Rev Panam Salud Publica 2002; I (3): 178-85.
106. Gotzsche PC, Nielsen M. Screening for breast cancer with mammography. Cochrane Database Syst Rev 2006(4):CD00I877. 107. Smith RA, Caleffi M, Albert US, Chen TH, Duffy SW, Franceschi D, et al. Breast cancer in limited-resource countries: early detection and access to care. Breast J 2006;12 Suppl I:SI6-26.

108. Comisión Nacional de Protección Social en Salud. Sistema de Protección Social en Salud: Informe de resultados al primer semestre de 2008. México D.F:: Secretaría de Salud; 2008.

109. Frenk J, Gonzalez-Pier E, Gomez-Dantes O, Lezana MA, Knaul FM. [Comprehensive reform to improve health system performance in Mexico]. Salud Publica Mex 2007;49 Suppl I:S23-36.

I I0. Lauver D, Ho C-H. Explaining Delay in Care Seeking for Breast Cancer Symptoms. J Appl Soc Psych 1993;23(2I):1806-1825.

II I. King RA, Leach JE. Factors contributing to delay by patients in seeking medical care. Cancer 1950;3(4):57I-9.

1 12. Greer S. Psychological aspects: delay in the treatment of breast cancer. Proc R Soc Med 1974;67(6 Pt I):470-3.

I I3. Facione NC. Delay versus help seeking for breast cancer symptoms: a critical review of the literature on patient and provider delay. Soc Sci Med 1993;36(I2):152I-34.

I 14. Ahmed R, McLatchie GR. Concealed breast cancer causes delayed treatment. BMJ 1998;316(7146): 1744.

II5. Cameron A, Hinton J. Delay in seeking treatment for mammary tumors. Cancer 1968;2I(6):II2I-6.

I 16. Goldsen RK, Gerhardt PR, Handy VH. Some factors related to patient delay in seeking diagnosis for cancer symptoms. Cancer 1957; I0(I):I-7.

1 17. Burgess CC, Ramirez AJ, Smith P, Richards MA. Do adverse life events and mood disorders influence delayed presentation of breast cancer? J Psychosom Res 2000;48(2): 17I-5.

I 18. Kunkel EJ,Woods CM, Rodgers C, Myers RE. Consultations for 'maladaptive denial of illness' in patients with cancer: psychiatric disorders that result in noncompliance. Psychooncology 1997;6(2):139-49. I 19. Watson M, Greer S, Blake S, Shrapnell K. Reaction to a diagnosis of breast cancer. Relationship between denial, delay and rates of psychological morbidity. Cancer 1984;53(9):2008-12.

120. Huguley CM, Jr., Brown RL. The value of breast self-examination. Cancer 1981;47(5):989-95.

I2I. Caplan LS, Helzlsouer KJ, Shapiro S, Freedman LS, Coates RJ, Edwards BK. System delay in breast cancer in whites and blacks. Am J Epidemiol 1995; I 42(8):804-I2.

122. Facione NC. The J-Delay scale: a measure of the likelihood of patient delay in breast cancer. Res Theory Nurs Pract 2002;16(2):103-18.

123. Arndt V, Sturmer T, Stegmaier C, Ziegler H, Becker A, Brenner $H$. Provider delay among patients with breast cancer in Germany: a population-based study.J Clin Oncol 2003;2I(8):1440-6. 